\title{
Voting, Education, and the Great Gatsby Curve
}

\author{
Christopher Rauh* \\ University of Cambridge
}

\begin{abstract}
High inequality goes hand in hand with low intergenerational earnings mobility across countries. Little is known about why the US is characterized by high inequality and low mobility, while the opposite tends to hold for Scandinavian countries. In an overlapping generations model, calibrated to the US, education policies are endogenized via probabilistic voting. By exploiting cross-country variation in the bias in voter turnout towards the educated and elderly, the model replicates the negative relation between inequality and public education expenditures and accounts for more than a quarter of the variation in inequality and mobility. For the US, I find that compulsory voting could foster mobility, whereas inequality would be hardly affected.
\end{abstract}

Keywords:

Inequality, Intergenerational Mobility, Political Economy, Education, Great Gatsby Curve, Voting

*The paper was previously circulated under the title "The Political Economy of Early and College Education - Can Voting Bend the Great Gatsby Curve?". I am grateful to Nezih Guner for his support and comments. I would also like to thank Toke Aidt, Claustre Bayona, Tiago Cavalcanti, Joan Esteban, Javier Fernández Blanco, Carlos Garriga, Giacomo de Giorgi, Jeremy Greenwood, Keith Henwood, Ezgi Kaya, John Knowles, Sarolta Laczó, Hannes Mueller, Kiku Obiols, Akash Raja, Rajesh Ramachandran, Alison Rauh, Alexandra Roulet, Arnau Valladares-Esteban, Jack Willis, and Yanos Zylberberg for their helpful feedback and discussions. I acknowledge financial support from the INET Institute of the University of Cambridge and from the Barcelona Graduate School of Economics through the Severo Ochoa Program for Centers of Excellence (SEV-20110075).

Email address: cr542@cam.ac.uk (Christopher Rauh) 


\section{Introduction}

Ever since the presidential address by Alan Krueger in 2012, the empirical finding of a positive correlation between earnings inequality and intergenerational earnings persistence has gained international fame as the "Great Gatsby Curve". 1 This paper investigates a political explanation for why countries are located at different points along the curve. Why does the US appear at one end of the curve, exhibiting high inequality and high persistence, while most Scandinavian countries are characterized by low inequality and low persistence? More specifically, I study whether variation in voter turnout rates - and the associated differences in public education programs - can explain cross-country variation in intergenerational persistence and inequality. A model is specified, which allows me to quantify the contribution of differences in voter turnout by age and education, and moreover permits the simulation of counterfactual voting policies.

The paper can be summarized in terms of two findings: first, exploiting the skewness of voter turnout by age and education, the model can consistently reproduce patterns of intergenerational mobility observed across countries; second, policies of compulsory voting or extending the electoral franchise to children by letting their parents vote for them could foster mobility in the US.

Education is a strong determinant of earnings, and public provision of education may enhance earnings mobility by raising the education level of the poor. According to traditional voting models, the provision of public education, in particular non-tertiary education, is expected to be higher when the share of earnings held by the rich is greater. However, the share of GDP dedicated to non-tertiary or tertiary public education is negatively associated with inequality across countries, as shown in Figure 2 in Section 2. This could occur if the affluent prefer private education and public policies are biased in their favor. Indeed, private education expenditures are found to be positively associated with inequality across countries. Under the assumption that the rich prefer private education, this could be driven by a bias in voter turnout. ${ }^{2}$

The quantitative model consists of two building blocks, namely an economic and a political part. First, the economic part adopts a structure resembling that

\footnotetext{
${ }^{1}$ The name was adopted from the novel "The Great Gatsby", in which the author F. Scott Fitzgerald challenges the "American Dream" by telling the story of Jay Gatsby, who rises to the high society via shady deals.

${ }^{2}$ Surveys indicate that preferences for more public education are negatively related to income (e.g., Busemeyer 2012).
} 
of Restuccia and Urrutia (2004). Parents invest in early private education, a substitute to public education, to enhance the imperfectly-inherited ability of their offspring. Subsequently, households decide whether or not to send children to college, where the more able students are less likely to drop out. Human capital formation is characterized by the dynamic complementarity between early and late investments (e.g., Cunha and Heckman 2008, Cunha et al. 2010, Caucutt and Lochner 2012). ${ }^{3}$ I add savings and retirement to Restuccia and Urrutia (2004), whereby individuals consume their savings and a public pension during retirement. Second, in the political part of the model, I let households vote on public education, the replacement rate, and a lump-sum redistributive payment. Thus, early public education expenditures and the slope of the college subsidy relative to parental earnings are determined endogenously.

In the model economy, public education expenditures are endogenous and households vote via probabilistic voting. Households vote in their own interest and without altruistic preferences for society as a whole. Probabilistic voting allows me to exploit the skewness of voter turnout by age and level of education across countries in order to explain variations in education expenditures and the effects on inequality and mobility. When modeling the political economy, De la Croix and Doepke (2009) and Ichino et al. (2011) emphasize the importance of the responsiveness of politicians to low-income families in the determination of education funding. The voting channel embedded in my model provides a rationale, namely political participation, as to why we might observe differences in the responsiveness across countries. The weights of individuals in the voting process are assigned according to voter turnout by age group and level of education using the voting supplement of the Current Population Survey (CPS) of 2006 for the US. For the experiments, I use the 2010 European Social Survey and the 2008 Canadian Election Study. I find that observed patterns of public and private education expenditures, inequality, and intergenerational mobility can be reconciled by voter

\footnotetext{
${ }^{3}$ I use the expression "non-tertiary" or "early" to summarize primary and secondary education. Given the evidence on the early formation of cognitive and non-cognitive skills (e.g., Cunha et al. 2006), the consideration of pre-primary education is an important factor in the examined dynamics and outcomes from which I abstract. Peer and neighborhood effects, as well as health, are other channels through which parental income could affect the learning aptitude of children that are worth mentioning, but are not included in the model. Also, parental connections could contribute to the intergenerational linkage of earnings. Corak and Piraino (2011) find that about $40 \%$ of young Canadian men have worked for an employer who had previously employed their father at some point in time, while 6-9\% have the same employer in adulthood. The percentage increases with paternal earnings.
} 
turnout. The counterfactual experiment accounts for $27 \%$ of the variation in intergenerational mobility and $31 \%$ of the variation in the Gini index. As a robustness check, I repeat the analysis, but instead weight voters by the fraction of political party members per age group and education level. The data is obtained from the World Values Survey 1981-2007 (WVS) and the results exhibit similar patterns. This indicates that the political participation of a society, whether through voting or party membership, shapes public policy, thereby influencing inequality and intergenerational mobility.

Given that patterns of voter turnout perform well in explaining cross-country differences, I consider a range of possible voting policies for the US. One studied policy is the enforcement of compulsory voting. The possible effects of compulsory voting on inequality have been studied by Chong and Olivera (2008), who, in a cross-country analysis, find that compulsory voting is associated with a more equal income distribution. In another experiment, I allow parents to vote on behalf of their children. I find that the earnings persistence is reduced by $17 \%$ under compulsory voting, whereas the extension of the electoral franchise to children as of birth reduces earnings persistence by one quarter. However, the equalizing effect of these policies on pre-tax earnings is comparably low. Additional policies considered are lowering the voting age from 18 to 16 and using a proportional instead of lump-sum education subsidy.

My paper contributes to the literature building on Becker and Tomes (1979, 1986) and Loury (1981), who pioneered the microfoundation of the three fundamental institutions in the determination of a child's future: the family, the labor market, and the state. The papers that build on these frameworks and are most closely related to my approach are Restuccia and Urrutia (2004), Herrington (2015), and Holter (2015), who use dynastic overlapping generations models to quantitatively study intergenerational mobility. Assuming exogenous taxation and education policies, Restuccia and Urrutia (2004) find that increasing early education expenditures would be more efficient than increasing college subsidies in reducing intergenerational persistence. Herrington (2015) accounts for a share of the gap in inequality and intergenerational persistence between Norway and the US through variations in the allocation of public spending and revenue sources. Holter (2015) exploits cross-country differences in the progressivity of income taxation to explain part of the gap in intergenerational mobility between the US and ten OECD countries. However, in all of the previously mentioned approaches, public education expenditures are taken to be exogenous. This inevitably leads to the question of the political economy of policies. My approach sheds light on a driver of cross-country differences in tax and education policies, and allows me to 
conduct counterfactual simulations that provide insights into the effects of voting policies on inequality and intergenerational mobility.

The remainder of the paper is organized as follows: Motivating stylized facts are presented in Section 2. The model is explained in Section 3 with the equilibrium definition following in Section 4. The parameterization is described in Section 5, while Section 6 gives the benchmark results and discusses policy experiments for the US. In Section 7, experiments explain differences between the US benchmark economy and other OECD countries. The robustness of these results is analyzed in Section 8. Finally, Section 9 concludes.

\section{Stylized facts}

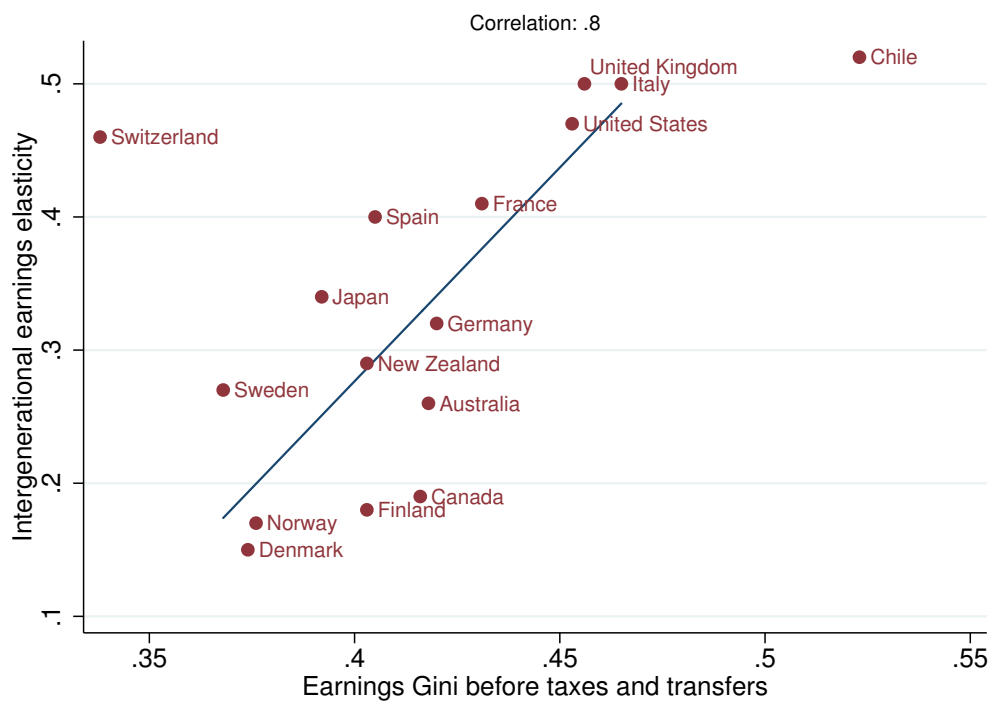

Figure 1: The Great Gatsby Curve

Sources: Gini from OECD (2013a); IEE from Corak (2013a).

Notes: The figure displays inequality measured by the Gini coefficient (x-axis) versus intergenerational earnings persistence in terms of the IEE (y-axis). The fitted line and the correlation coefficient are computed excluding the outliers, Chile and Switzerland.

Figure 1 shows that inequality in terms of the Gini coefficient of individual earnings before taxes and transfers and the intergenerational earnings elasticity (IEE) exhibit a strong positive correlation across countries. The IEE is the coefficient obtained by regressing the log of a son's earnings on the log of paternal 
earnings, and captures the percentage change in a son's adulthood earnings that is associated with a one percentage point increase in paternal earnings. ${ }^{4}$

Figure 2 presents stylized evidence across countries that redistributive expenditures in terms of public education do not match the predictions of a standard median voter framework. The top panels show how inequality is negatively associated with the share of GDP spent on public education. This relationship holds for both non-tertiary (left panel) and tertiary (right panel) public education across countries. The most unequal countries, such as Chile, Italy, and Mexico, tend to spend less on both early and late public education. At the same time, more equal countries, such as Denmark, Norway, and Sweden, are amongst the top spenders at both stages. The bottom panels show that the opposite holds for private expenditures, i.e. household expenditures are positively related to inequality, indicating that in countries where inequality is higher, education might depend more on the unequally-distributed parental earnings.

Through the channel of differential political participation, the model introduced in the following section reconciles both the traditional voting models' prediction of a positive relation between inequality and public education expenditures within a country and the negative relationship observed in cross-country data.

\section{The model}

The model consists of two parts, namely the economic and the political decisions. In the following sections, the economic decision framework is outlined before I turn to the political decision framework in Section 3.5.

\subsection{Economic decision framework}

The overlapping generations model builds on Restuccia and Urrutia (2004). A household makes economic decisions as a single unit, exists for three periods, and is composed of either young parents and young children (young household), old parents and old children (old household), or retired parents (retired household). In the subsequent period, retired parents die, while the old children become young parents and form households of their own. Consequently, everybody lives for five

\footnotetext{
${ }^{4}$ The IEE is computed by averaging the earnings of fathers and sons over as many years as are available in panel data in order to reduce measurement error and attrition bias through transitory earnings shocks. As the paper focuses on education, both the Gini and the IEE are based on labor earnings before taxes and transfers, i.e. returns to human capital.
} 
(a) Public expenditures on education
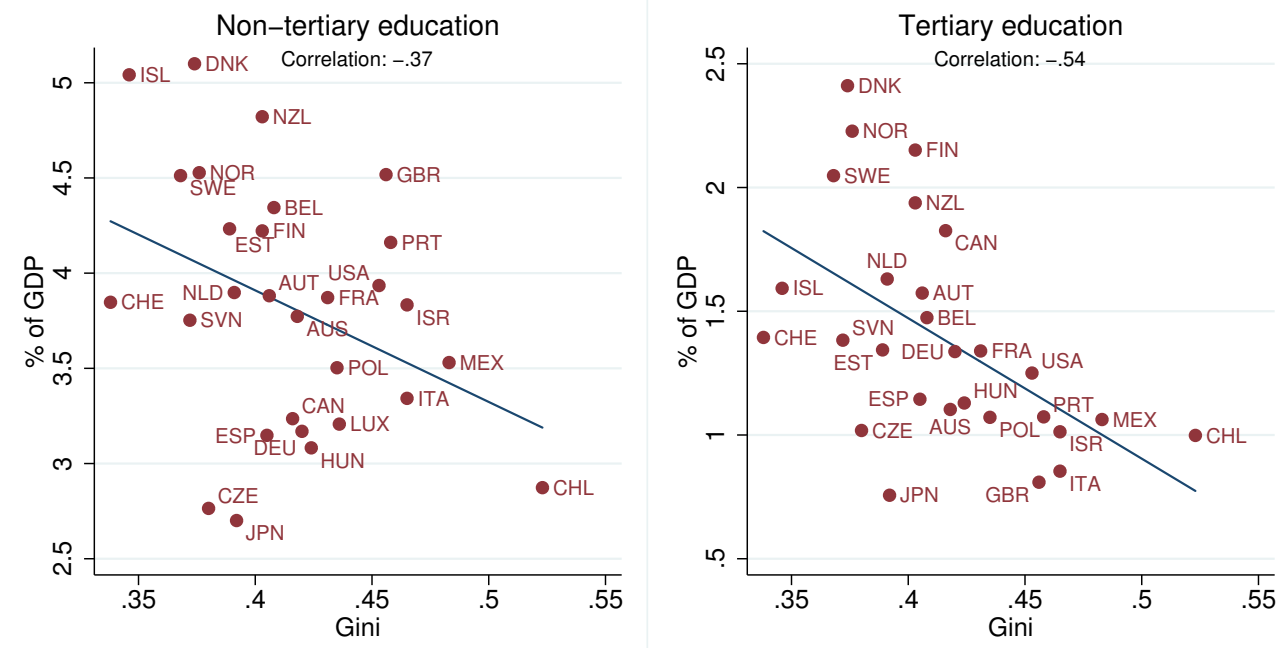

(b) Private expenditures on education
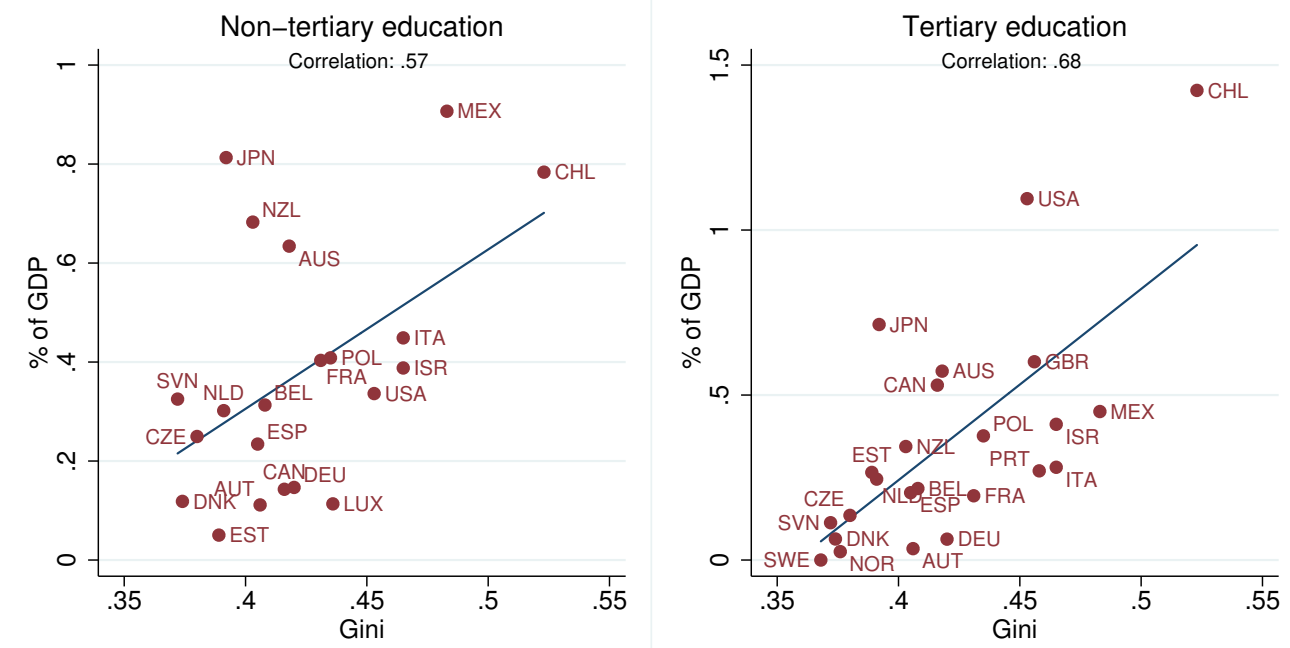

Figure 2: Inequality versus public and private education expenditures

Data sources: Gini from OECD (2013a); education expenditures from OECD (2011).

Notes: The figure displays inequality (Gini before taxes and transfers) on the $\mathrm{x}$-axis versus education expenditures (in terms of $\%$ of GDP) on the y-axis. The top panels display public and the bottom panels private (i.e. household) education expenditures. The left and right panels refer to non-tertiary and tertiary education expenditures, respectively. 
periods, but only makes economic decisions during the last three periods. Population growth is zero and all parents have the same number of children, i.e. each household has two identical children. ${ }^{5}$ Parents make education decisions for their children and households are heterogeneous in the levels of innate ability of the offspring, human capital of the parents, and accumulated physical assets. Lifetime utility is derived from consumption as a young household $c_{y}$, old household $c_{o}$, retired household $c_{r}$, and altruism regarding the level of human capital a child is left behind with. Consumption is pooled at the household level and is subject to congestion. The utility function for consumption $u(c)$ is increasing and concave. Labor is provided inelastically and human capital is remunerated by competitive firms at a wage rate $w$. Retired households consume their savings $k$, which are subject to a risk-free exogenous interest rate $r$, as well as a public pension $p$, which is a fraction of previous earnings.

\subsection{Ability and human capital}

Children's innate ability is assumed to be correlated with parental innate ability. Innate ability is not altered over the lifecycle and can be interpreted as the genetic component. Acquired ability $\hat{a}$ is a function of innate ability and public and private education investments when young, which later affect the probability of college completion and wages. When a child is old, acquired ability $\hat{a}$ transforms into human capital $h_{c}$. After becoming a parent, human capital evolves exogenously, while capturing the lifecycle-earnings profile. When becoming a young parent, human capital experiences a shock and converts to $h_{y}$, whereas for the old parent human capital is denoted by $h_{o}$.

Innate ability $a$, when passed from one generation to the next, follows a firstorder discrete Markov process with mean normalized to one and transition matrix $\Psi$. The vector of states for $a$ and the elements in the transition matrix are restricted such that the process is a discrete approximation of a continuous AR(1) process as in

$$
\ln \left(a^{\prime}\right)=\rho \ln (a)+\varepsilon \text { where } \varepsilon \sim N\left(0, \sigma_{a}^{2}\right) .
$$

Innate ability $a$ is transformed into acquired ability $\hat{a}$ via public education $g$ and private early education $e$ according to the function $f(a, e, g)$ when the off-

\footnotetext{
${ }^{5}$ While De la Croix and Doepke (2004) demonstrate theoretically how differential fertility rates might play a considerable role in the distribution of human capital investments and preferences for public education among families, Björklund et al. (2004) find no differences in intergenerational mobility by family size using Norwegian data.
} 
spring is young. The function $f(a, e, g)$ is assumed to be positive, strictly increasing, and concave in all its arguments. Public and private education are treated as perfect substitutes. Following the literature on early skill formation, acquired ability $\hat{a}$ is increasing in innate ability $a$. Also the return to investment in education is increasing in innate ability, such that $\frac{\partial^{2} f}{\partial a \partial e}, \frac{\partial^{2} f}{\partial a \partial g}>0$, as skill has been found to beget skill (Cunha et al. 2006, Cunha and Heckman 2008). The functional form is assumed to be given by

$$
\hat{a}=f(a, e, g)=\delta a^{1-\gamma}(g+e)^{\gamma} .
$$

The curvature of $f$ changes with the parameter $\gamma$, which is also responsible for the relative importance of innate ability versus investment. The parameter $\delta$ is the efficiency parameter regulating the level effect of human capital creation.

Everybody enjoys public education, while choosing the preferred level of private education to top up. This sort of structure is not limited to the growing number of charter schools. Investments in early private education can be imagined as anything from piano lessons to out-of-school tutoring. Data for the US reveals that the gap in "enrichment expenditures" between poor and rich parents has become greater over time (Duncan and Murnane 2011, Kornrich and Furstenberg 2013).

When children are old, the household decides whether or not they should go to college $s \in\{0,1\}$. Children not going to college work the entire period, whereas going to college implies spending a share $\underline{v}$ of the period in college in case of dropping out, and a share $\bar{v}$ in case of completion, while working the rest of the period. The earnings of the offspring are shared with parents at the household level. If a child goes to college, he/she graduates with probability $\pi(\hat{a})$, thus dropping out with probability $(1-\pi(\hat{a}))$. The probability $\pi$ of completing college is increasing in acquired ability and is given by

$$
\pi(\hat{a})=\min \left\{1, \psi_{0}(1+\hat{a})^{\psi_{1}}\right\}
$$

where $\psi_{0}, \psi_{1}>0 .^{6}$ The parameter $\psi_{0}$ is responsible for the level effect of acquired ability on completion, while the convexity of the function is increasing in $\psi_{1}$. College education comes at a tuition $\operatorname{cost} T$ per period. The government subsidizes a share $q$ of the tuition cost $T$ depending on parental earnings according to

$$
q\left(h_{o}\right)=\max \left\{0, \kappa_{0}-\kappa_{1} h_{o}\right\}
$$

\footnotetext{
${ }^{6}$ Light and Strayer (2000) and Chatterjee and Ionescu (2012) provide evidence that graduation rates are increasing in ability measured by pre-entry test scores.
} 
where the parameters $\kappa_{0}$ and $\kappa_{1}$ determine the intercept and the slope of the college subsidy, respectively. The subsidy is bounded from below by 0 , such that no household has to pay an additional fee, and above by 1 , thereby ensuring that no household receives a subsidy beyond compensation of the actual cost of attending college.

Acquired ability is multiplied by $\bar{\theta}$ if the offspring completes college and by $\underline{\theta}$ if he/she drops out (where $\bar{\theta}>\underline{\theta}$ ). Therefore, the earnings differential between non-college and college graduates observed in society is composed of two components, namely the endogenously-acquired prior ability and the exogenous earnings boost $\bar{\theta}$. The acquired ability is mapped into human capital of the old child $h_{c}$ by

$$
h_{c}= \begin{cases}\hat{a} & \text { if does not attend college } \\ \bar{\theta} \hat{a} & \text { if completes college } \\ \underline{\theta} \hat{a} & \text { if drops out of college }\end{cases}
$$

where the college completion probability is given by (3). This functional form satisfies the dynamic complementarity between early and late investments in human capital discussed by Cunha et al. (2006) and Cunha and Heckman (2008). The final level of education obtained, denoted as $b$, can either be high school, college dropout, or college graduate.

Two things occur when transitioning from an old child to a young parent. Firstly, individuals experience a shock $\zeta$, commonly referred to as market luck. The shock accounts for the fact that earnings dispersion within a cohort increases over the lifecycle (Huggett et al. 2006) and for the finding by Huggett et al. (2011) that only $61 \%$ of the variance in lifetime earnings can be attributed to pre-working conditions. The shock is multiplicative and is drawn from a truncated normal distribution $\zeta \sim N\left(1, \sigma_{\zeta}^{2}\right)$. This shock creates no aggregate uncertainty and is permanent. Secondly, their human capital increases exogenously by the lifecycle component $\eta_{0}>1$, such that

$$
h_{y}=\eta_{0} \zeta h_{c} .
$$

Young parents are equipped with human capital $h_{y}$ and choose how much to invest in private early education $e$. Old parents have human capital $h_{o}$, which is given by

$$
h_{o}=\eta_{1} h_{y}
$$

where $\eta_{1}>1$ represents the increase in the earnings profile through experience later in the lifecycle. Earnings are determined by human capital and the competitive wage $w$, the rate of return to human capital in the market. For simplicity, $w$ is normalized to unity in what follows. 


\subsubsection{Borrowing and saving}

Households can accumulate capital $k$, which yields an exogenous interest $r$ per period. For reasons of tractability, households are not able to borrow. Given that college has become more expensive, the importance of the increased uptake of student loans has been receiving attention (Lochner and Monge-Naranjo 2012, Abbott et al. 2013, Belley et al. 2014). The fact that one period in the model spans several years could be interpreted as perfect intertemporal borrowing within a given period, thereby addressing the lack of borrowing to some extent.

\subsection{Households}

Households take taxes $\tau$, the public pension $p\left(h_{o}\right)$, and redistribution payments $d$, as well as public expenditures on early education $g$ and the college education subsidy $q\left(h_{o}\right)$ for all $t$ as given when maximizing lifetime utility, discounted by $\beta<1$. The utility of consumption is derived with constant relative risk aversion as in $u(c)=\frac{c^{1-\sigma}}{1-\sigma}$, while the utility derived from the child's final human capital is valued by $\phi_{0} h_{c}^{\phi_{1}}$, where $\phi_{0}$ is responsible for the level effect and $\phi_{1}$ determines the curvature $\left(\phi_{0}, \phi_{1}>0\right){ }^{7}$

A retired household consumes its savings $k$, public pension $p\left(h_{o}\right)$, and redistribution payments $d$. The pension a household enjoys is linked to its previous earnings and is given by

$$
p\left(h_{o}\right)=\xi h_{o} .
$$

Simply speaking, the pension is a fraction $\xi$ of labor income earned as an old parent. Therefore, the problem of the retired household is mechanic in nature and can be written as

$$
\begin{aligned}
& V_{r}\left(k, h_{o}\right)=u\left(c_{r}\right), \\
& \text { subject to } \\
& c_{r}=p\left(h_{o}\right)+(1+(1-\tau) r) k+d, \\
& p\left(h_{o}\right)=\xi h_{o} .
\end{aligned}
$$

Let the mass of retired households be $\mu\left(x_{r}\right)$ and all variables affecting its decisions be summarized by $x_{r}=\left(k, h_{o}, b\right)$.

The state variables of the old household are $\left(k, h_{o}, \hat{a}\right)$. Let $z$ be equal to one if a child completes college and zero in the case of dropping out. Therefore, the

\footnotetext{
${ }^{7}$ Parents value their children's human capital rather than the expected discounted future utility flow of the dynasty for computational convenience. While this choice has a minor impact for their investment decision, as human capital is closely related to expected utility flows, it leads to retired households mechanically opposing early education in the voting process.
} 
problem of the old parent household can be written as

$$
V_{o}\left(k, h_{o}, \hat{a}\right)=\max _{s \in\{0,1\}}\left\{V_{o}^{s 0}\left(k, h_{o}, \hat{a}\right), E_{z}\left[V_{o}^{s 1}\left(k, h_{o}, \hat{a}, z\right)\right]\right\}
$$

where $V_{o}^{s 0}\left(h_{o}, \hat{a}\right)$ is the value function of not sending children to college, and $V_{o}^{s 1}\left(k, h_{o}, \hat{a}, z\right)$ is the value of sending them to college, which depends on the college completion probability given by (3). The value of not sending children to college is given by

$$
\begin{aligned}
& V_{o}^{s 0}\left(k, h_{o}, \hat{a}\right)=\max _{c_{o}, k^{\prime} \geq 0}\left\{\frac{\left(\frac{c_{o}}{\chi}\right)^{1-\sigma}}{1-\sigma}+\phi_{0} h_{c}^{\phi_{1}}\right\} \\
& \text { subject to } \\
& c_{o}+k^{\prime}=(1-\tau) h_{o}+(1-\tau)\left(h_{c}+r k\right)+k+d, h_{c}=\hat{a} .
\end{aligned}
$$

where $\chi$ is the congestion in consumption due to having children at home. The expected value of sending children to college conditional on completion $z$ is

$$
\begin{aligned}
& E_{z}\left[V_{o}^{s 1}\left(k, h_{o}, \hat{a}, z\right)\right]=\pi(\hat{a}) V_{o}^{s 1}\left(k, h_{o}, \hat{a}, 1\right)+(1-\pi(\hat{a})) V_{o}^{s 1}\left(k, h_{o}, \hat{a}, 0\right), \\
& \text { where } \\
& V_{o}^{s 1}\left(k, h_{o}, \hat{a}, z\right)=\max _{c_{o}, k^{\prime} \geq 0}\left\{\frac{\left(\frac{c_{o}}{\chi}\right)^{1-\sigma}}{1-\sigma}+\phi_{0} h_{c}^{\phi_{1}}\right\} \\
& \quad \text { subject to } \\
& c_{o}+k^{\prime}+\left(1-q\left(h_{o}\right)\right)(z \bar{v}+(1-z) \underline{v}) T= \\
& (1-\tau) h_{o}+(1-(z \bar{v}+(1-z) \underline{v}))(1-\tau)\left(h_{c}+r k\right)+k+d, \\
& h_{c}=(z \bar{\theta}+(1-z) \underline{\theta}) \hat{a}
\end{aligned}
$$

with the probability $\pi(\hat{a})$ of completing college given by (3) and the college subsidy $q\left(h_{o}\right)$ by (4). Let the distribution of old parent households be summarized by $\mu\left(x_{o}\right)$, where $x_{o}=\left(k, h_{o}, \hat{a}, a, b\right)$, and let $s\left(x_{o}\right), k_{o}\left(x_{o}\right)$, and $c_{o}\left(x_{o}\right)$ be the solutions to (10), and thus the policy functions of the college decision, savings, and consumption of the old household, respectively.

The state variables of the young household are $\left(h_{y}, a\right)$ and their problem is given by

$$
\begin{aligned}
& V_{y}\left(h_{y}, a\right)=\max _{e, c_{y}, k^{\prime} \geq 0}\left\{\frac{\left(\frac{c_{y}}{\chi}\right)^{1-\sigma}}{1-\sigma}+\beta V_{o}\left(h_{o}^{\prime}, \hat{a}^{\prime}\right)\right\} \\
& \text { subject to } \\
& c_{y}+e+k^{\prime}=(1-\tau) h_{y}+d, \\
& \hat{a}^{\prime}=\delta a^{1-\gamma}(g+e)^{\gamma} \\
& h_{o}^{\prime}=\eta_{1} h_{y} .
\end{aligned}
$$


Let $x_{y}=\left(h_{y}, a, b\right)$ and let $c_{y}\left(x_{y}\right), k_{y}\left(x_{y}\right)$, and $e\left(x_{y}\right)$ be the policy functions of consumption, savings, and early private education associated with the young, respectively. The distribution of young parent households is described by $\mu_{y}\left(x_{y}\right)$. The total mass of households is assumed to be constant and of mass unity per period of the lifecycle. Therefore, the total mass of individuals is five (since the young and old parents have children at home).

\subsection{Government}

The government levies taxes on asset and labor income using a proportional $\operatorname{tax} \tau$. The money the government raises is spent on early and late education, as well as on lump-sum redistribution and a public pension. More specifically, $\tau_{g}$ is used to finance public early education $g$, while the share $\tau_{q}$ covers part of tuition cost $T$ for those going to college. Therefore, government expenditures $g$ on early education are given by

$$
g=\tau_{g} Y .
$$

The college subsidy depends not only on $\tau_{q}$ and total production in the economy, but also on the composition of college students. More specifically, it depends on the mass of students attending college, how long they attend, and what the earnings of their parents are. The government budget for tertiary education can be summarized by

$$
T \int s\left(x_{o}\right) q\left(h_{o}\right) v(\hat{a}) d \mu_{o}\left(x_{o}\right)=\tau_{q} Y
$$

where $q\left(h_{o}\right)$ is given by (4), $v(\hat{a})=\pi(\hat{a}) \bar{v}+(1-\pi(\hat{a})) \underline{v}$ is the time spent in college, and $\pi(\hat{a})$ is given by (3). Assuming no change in the composition of students, an increase in $\kappa_{1}$ leads to an increase in $\kappa_{0}$, which for a poorer household that send its offspring to college increases the subsidy rate $q$ as long as their earnings are not too high and satisfy $h_{o}<\frac{\kappa_{0}}{\kappa_{1}}$.

For public pensions, the government balances

$$
\int p\left(h_{o}\right) d \mu_{r}\left(x_{r}\right)=\tau_{p} Y
$$

where $p\left(h_{o}\right)$ is given by (8). An increase in $\tau_{p}$ translates into an increase in $\xi$, the fraction of previous earnings one receives during retirement. Finally, $\tau_{d}$ finances the total of lump-sum redistributions $D$, which are uniformly distributed across households as payment $d$. The total spent on redistribution $D$ is given by

$$
D=\tau_{d} Y .
$$


Together, these four tax rates sum up to the proportional tax rate $\tau$, which is levied on asset and labor income.

\subsection{The political decision framework}

Households vote on the level $\tau_{g}$ of early education expenditures determining $g$. The share $\tau_{q}$ of $Y$ dedicated to the college subsidy is held fixed, while households vote on $\kappa_{1}$, the slope of the college subsidy, which endogenously determines $\kappa_{0}$, the intercept. ${ }^{8}$ The publicly financed share of $Y$ dedicated to social expenditures, i.e. pension expenditures and redistribution, is held fixed at $\tau_{s}$. Households then vote on how the revenue accruing from $\tau_{s}$ is split up among pension payments $P$ and lump-sum redistribution payments $D$. In practical terms, households vote on $\tau_{p}\left(\leq \tau_{s}\right)$, which pins down $\tau_{d}$ as the residual, i.e. $\tau_{d}=\tau_{s}-\tau_{p}{ }^{9}$

The two proportional tax rates $\tau_{g}$ and $\tau_{p}$, and the slope of the college subsidy $\kappa_{1}$, are determined jointly through probabilistic voting, which allows for a weighted average of preferences across households instead of relying on the median voter. ${ }^{10}$ Due to the multi-dimensionality of the problem, preferences are unlikely to be single-peaked, thereby not allowing for the identification of the median voter.

In probabilistic voting, parties commit to policies before elections take place. The policy platform is chosen by opportunistic candidates who only care about being elected. It is assumed that parties differ along an ideological dimension observable to voters. Candidates know the ideological preference distribution of the voters, wherefore chosen policies are directed towards those voters that are less driven by the ideological component. Candidates have an average popularity common to all voters, which is a random variable and could be subject to a shock such as a scandal occurring on the day before elections take place. Since the policy platform is chosen when the outcome is uncertain, parties maximize the expected share of votes and thus the probability of winning the election. There exists a

\footnotetext{
${ }^{8}$ Having households vote on the slope emphasizes the interests of richer versus poorer households. For a given amount of total funding, poorer households prefer a steeper slope as this increases the intercept, while richer households prefer a flat subsidy schedule.

${ }^{9}$ This relation between $\tau_{d}$ and $\tau_{p}$ is required to reduce the dimensionality of the voting problem.

${ }^{10}$ Voters do not decide on the actual shape of the tax function, which is linear. Herrington (2015) and Holter (2015) find that the progressivity of the tax schedule plays an important role. Additionally, Herrington finds that public expenditures on early education are not always uniformly distributed across households as in my model, which could be an outcome of the political economy, as well. Due to computational complexity, I abstract from these characteristics.
} 
unique political equilibrium in which both parties propose the same policy by maximizing a weighted social welfare function, where weights are determined by the responsiveness of voters to policies, which might vary due to the ideological component (see Lindbeck and Weibull 1987, Persson and Tabellini 2002). I use voter turnout by age and level of education as weights in the voting process because candidates might be best off catering to the segment of population actually voting, an idea similar in spirit to Hettich and Winer (1984).

The decision voters make does not only depend on tax rates in $t$, but also on tax rates in the future (denoted by a prime), which will be decided upon in the following periods. Therefore, the current policy choices $\left(\tau_{g}, \tau_{p}, \kappa_{1}\right)$ depend on anticipated future policy choices $\left(\tilde{\tau}_{g}^{\prime}, \tilde{\tau}_{p}^{\prime}, \tilde{\kappa}_{1}^{\prime}\right)$ for three reasons; first, the choices will affect the level of taxation; second, these shares will affect disposable income through the residual redistributive payment $d$; third, the shares will determine public early education expenditures, college subsidies, and the pension directly.

It is assumed that when voting on the preferred policy in $t$, they take the anticipated values of the future to be the same as those chosen in $t$ and ignore the impact that their choice will have on future policy choices. In other words, agents assume that a chosen policy will be in place forever. Since agents are atomistic, this is a plausible assumption as they do not influence the outcome by themselves. In the steady state equilibrium, agents have rational expectations. Agents take into account how policy choices affect aggregate economic decisions and thus consider how $g, d$, and the functions $q\left(h_{o}\right)$ and $p\left(h_{o}\right)$ react now and in the future.

The welfare function $W$ is composed of the weighted discounted values of the old children $(o c)$, young parents $(y)$, old parents $(o p)$, and retired households $(r)$, and is maximized over the set of tax rates. Assigning $\omega_{o c}$ as the weight of the old children, $\omega_{y}$ of the young parents, $\omega_{o p}$ of the old parents, and $\omega_{r}$ of the retired households in the voting process, which depend on their level of education $b$, the problem is

$$
\begin{gathered}
Z\left(\mu_{y}\left(x_{y}\right), \mu_{o}\left(x_{o}\right), \mu_{r}\left(x_{r}\right)\right)=\underset{0 \leq \tau_{g} \leq 1-\tau_{s}, 0 \leq \tau_{p} \leq \tau_{s}, \kappa_{1} \geq 0}{\arg \max } W \\
W=\sum_{i} \int \omega_{i}(b) V_{i}\left(x_{i}\right) d \mu_{i}\left(x_{i}\right) \text { where } i \in\{o c, y, o p, r\},
\end{gathered}
$$

where $V_{o c}\left(x_{o c}\right)=E_{z, a^{\prime}, h_{y}^{\prime}}\left[u\left(c_{o}\right)+\beta V_{y}^{\prime}\left(h_{y}^{\prime}, a^{\prime}\right)\right], V_{o p}=V_{o}$, and $\mu_{o p}\left(x_{o p}\right)=\mu_{o c}\left(x_{o c}\right)=$ $\frac{\mu_{o}\left(x_{o}\right)}{2}$. In other words, the distributions of old children and old parents account for half their respective household mass. However, their values $V_{j}$ are different as the expected value of old children depends on the shock realizations in their human 
capital accumulation and the ability transmission to their children, whereas old parents are concerned about retirement and the human capital accumulation of their children.

\section{Equilibrium}

Let total consumption of young, old, and retired households be $C_{y}=\int c_{y}\left(x_{y}\right) d \mu_{y}\left(x_{y}\right), C_{o}=\int c_{o}\left(x_{o}\right) d \mu_{o}\left(x_{o}\right)$, and $C_{r}=\int c_{r}\left(x_{r}\right) d \mu_{r}\left(x_{r}\right)$.

DEFINITION 1. Given prices, policies, and tax rates, $V_{y}$ solves the functional equations and the requisite budget constraints in (13), $V_{o}$ solves (10) satisfying (11) and (12), and $V_{r}$ solves (9), with $c_{y}\left(x_{y}\right), c_{o}\left(x_{o}\right), c_{r}\left(x_{r}\right), k_{y}\left(x_{y}\right), k_{o}\left(x_{o}\right), s\left(x_{o}\right)$, and $e\left(x_{y}\right)$ as associated policy functions.

1. Goods market clearing:

$$
\begin{gathered}
Y=H+r K=C_{y}+C_{o}+C_{r}+E+F+g \\
E=\int e\left(x_{y}\right) d \mu_{y}\left(x_{y}\right) \\
F=T \int s\left(x_{o}\right)(\pi(\hat{a}) \bar{v}+(1-\pi(\hat{a})) \underline{v}) d \mu_{o}\left(x_{o}\right)
\end{gathered}
$$

2. Labor market clearing:

$$
\begin{array}{r}
H=\int h_{y} d \mu_{y}\left(x_{y}\right)+\int h_{o} d \mu_{o}\left(x_{o}\right)+\int\left(\left(1-s\left(x_{o}\right)\right)+s\left(x_{o}\right)(\pi(\hat{a})(1-\bar{v}) \bar{\theta}+\right. \\
+(1-\pi(\hat{a}))(1-\underline{v}) \underline{\theta}) \hat{a} d \mu_{o}\left(x_{o}\right)
\end{array}
$$

3. Capital market clearing:

$$
K=\int k_{y}\left(k_{y}\right) d \mu_{o}\left(x_{o}\right)+\int k_{o}\left(x_{o}\right) d \mu_{r}\left(x_{r}\right)
$$

4. The government balances budgets (14), (15), (16), and (17), which determine $g, q, p$, and $d$.

5. The laws of motion $\Phi$ mapping from state $x_{y}=\left(h_{y}, a, b\right)$ of the young to state $x_{o}^{\prime}=\left(k^{\prime}, h_{o}^{\prime}, \hat{a}^{\prime}, a^{\prime}, b^{\prime}\right)$ of the old in the following period, such that $\mu_{o}^{\prime}\left(x_{o}^{\prime}\right)=$ $\Phi\left(\mu_{y}\left(x_{y}\right)\right)$, are given by (2) and (7). The laws of motion $\Omega$ mapping from state $x_{o}=\left(k, h_{o}, \hat{a}, a, b\right)$ of the old to state $x_{y}^{\prime}=\left(h_{y}^{\prime}, a^{\prime}\right)$ of the young and $x_{r}^{\prime}=\left(k^{\prime}, h_{o}, h_{y}^{\prime}, a^{\prime}, b\right)$ of the retired in the following period, $\left(\mu_{y}^{\prime}\left(x_{y}^{\prime}\right), \mu_{r}^{\prime}\left(x_{r}^{\prime}\right)\right)=$ $\Omega\left(\mu_{o}\left(x_{o}\right)\right)$, are given by (1), (5), and (6). 
6. The rates $\tau_{g}$ and $\tau_{p}$ to finance public education expenditures on early education $g$ and the public pension p, respectively, as well as $\kappa_{1}$, are given by (18). Moreover, $\tau_{d}$, which finances redistribution, and $\kappa_{0}$ are determined as residuals.

A stationary equilibrium is a competitive equilibrium in which policy functions, as well as subsidies, tax rates, redistribution, and pensions are constant. It is a fixed point in the voting problem, such that next periods' tax rates $\left(\tau_{g}^{\prime}, \tau_{p}^{\prime}, \tau_{d}^{\prime}\right)$ are equal to the solution for $\left(\tau_{g}, \tau_{p}, \tau_{d}\right)$, and $\kappa_{1}^{\prime}=\kappa_{1}$, which are the solutions to (18). Furthermore, the distributions $\mu_{y}\left(x_{y}\right)=\mu_{y}^{\prime}\left(x_{y}^{\prime}\right), \mu_{o}\left(x_{o}\right)=\mu_{o}^{\prime}\left(x_{o}^{\prime}\right)$, and $\mu_{r}\left(x_{r}\right)=$ $\mu_{r}^{\prime}\left(x_{r}^{\prime}\right)$ are stationary, hence the distributions can be summarized by $\mu(x)$.

\section{Model parameterization}

In order to analyze the US economy and conduct cross-country experiments, the model is calibrated to the US around 2010 by matching facts on inequality, mobility, and public and private education expenditures. The model is governed by 31 parameters summarized in Table 2. 14 parameters are either chosen from a priori information or are standard in the literature. The remaining parameters, of which five parameters emerge from the voting process, are determined in the calibration by simulated methods of moments with an equally weighted diagonal matrix, i.e. by minimizing the squared percentage deviation between 12 model and 14 data moments.

\subsection{Independently chosen parameters}

One period in the model is equivalent to 16 years. The discount rate is standard at 0.96 per year, which results in $\beta$ being set to 0.52 . I choose a standard value in the consumption literature of 1.5 for the intertemporal preference parameter $\sigma$. Following Holter (2015), I set the exogenous yearly interest rate to $r=0.011$ based on the 3-month T-bill rates minus inflation from 1947-2008 computed using data from the Federal Reserve Bank of St. Louis. College completion requires four years of attendance, which, given a period length of 16 years, translates into $\bar{v}=0.25$. Supported by evidence in Stinebrickner and Stinebrickner (2008), dropping out occurs after two years of college attendance $(\underline{v}=0.125)$. The increases in earnings through the lifecycle are determined by the earnings ratio of working males in the given age groups. For $\eta_{0}$, I take the ratio between those aged 33 and 48 to those between 22 and 32. For $\eta_{1}$, I take the ratio of males aged between 49 and 64 to those between 33 and 48. Using the IPUMS data of 2011, the increases in earnings over the lifecycle are determined to be $\eta_{0}=1.8$ and $\eta_{1}=1.1$. 


\subsubsection{Tax parameters}

According to the OECD, public social expenditures, i.e. the public pension, health, and income support, accounted for $19 \%$ of US GDP in 2010, which is the value chosen for $\tau_{s}$, the share of $Y$ dedicated to public pensions and lump-sum redistribution. ${ }^{11}$ The share of GDP dedicated to college grants is set to $\tau_{q}=0.002$, which is equivalent to what the federal government spent on pell grants in 20112012 according to the Congressional Budget Office (CBO). ${ }^{12}$

\subsubsection{Voting}

Participation in the elections of the President and of Congress is highly correlated with the level of education in the US. Since it is more likely for the higher educated to vote, politicians might be better off catering to their interests. In frameworks based on the median voter theorem, this has been incorporated in models by Benabou (2000) and Ichino et al. (2011) to account for the fact that the decisive voter might not actually be the median earner. Recent research points out the effects of skewed voter turnout and a bias in responsiveness towards policy preferences of the affluent (e.g., Gilens 2012, Schlozman and Brady 2012, Bonica et al. 2013). Additionally, the older an individual, the more likely he/she is to cast a vote. To account for these potential biases, I use the 2006 voting supplement of the CPS to compute the share of eligible individuals by education and age group that casted their vote in the 2006 election of Congress. The patterns of voter turnout by age and education are fairly constant across the three elections of Congress and the three presidential elections of previous years in the CPS data (1996-2006), as can be seen in Table 5 in the Appendix. The political science literature has established a cross-country relationship between inequality and voter turnout (e.g., Lijphart 1997), but to the best of my knowledge there is no empirical evidence of this relationship holding or being causal within a country. In addition, given that no theoretical model has been able to explain patterns of voter turnout consistently, participation is treated as exogenous. ${ }^{13}$

The voting weight within the old parent household $\omega_{o}$ is split into the sum of the weights assigned to the parents and the offspring. However, the old offspring have not taken all educational decisions yet, wherefore individuals in this age group are not weighted by education, but rather by the level of education of their parents. Otherwise, education expenditures could alter decisions, which in turn

\footnotetext{
${ }^{11}$ See OECD Social Expenditure database (SOCX).

${ }^{12}$ See https://www.cbo.gov/publication/44448.

${ }^{13}$ For more discussion about voter turnout, see Section 7.1.
} 
affects the voting weights of the old offspring. According to the data, on average $27 \%$ of those aged 18-32 turn out to vote. Given that their parents' education is exogenous at the moment of voting, I use the General Social Survey (Smith et al., 2015) to compute how parental education affects the likelihood of an individual aged 18-32 to vote. I find that having parents with at most high school, some college, and completed college education changes the probability relative to the average by $-6 \%,+2 \%$, and $+9 \%$, respectively. Finally, the weights for those aged 16-32 are multiplied by $7 / 8$ as in practice they would not be allowed to vote for $1 / 8$ of the period. The weights assigned to each age and education level are displayed in Table 1.

\begin{tabular}{lccc}
\hline \hline Age & High school or less & Some college & College \\
\hline $18-32$ & .23 & .25 & .26 \\
$33-48$ & .32 & .48 & .64 \\
$49-64$ & .47 & .63 & .77 \\
$65-80$ & .58 & .73 & .80 \\
\hline \hline
\end{tabular}

Table 1: Voting weights $\omega$

Data source: CPS November voting supplement 2006. Average voter turnout for individuals aged 18-32 is adjusted for parental education using the General Social Survey and by a factor of 7/8 to reflect the fact that they turn 18 after $1 / 8$ of a model period.

\subsection{Calibrated parameters and targets}

\subsubsection{Education costs and expenditures}

In 2009, the share of GDP dedicated to public early education was $3.9 \%$ (OECD 2011) and is targeted by $\gamma$, the productivity parameter of early education investment. ${ }^{14}$ The share of household wages parents spend on early private education serves as a target for the altruism parameters. Using the Consumer Expenditure Survey of 2010, I compute that parents on average spend $8.9 \%$ of

\footnotetext{
${ }^{14}$ Of total public expenditures in 2011, $12 \%$ was federal, $44 \%$ from the state, and $43 \%$ locally provided. By distributing total public education expenditures equally across pupils, I am overestimating equality of opportunity in the US as locally-provided public education is correlated with local income (Herrington 2015). Ideally, public education expenditures in the model would be chosen on a smaller geographical level, which unfortunately would not be computationally feasible.
} 
earnings on private early education for their children. ${ }^{15}$

In 2010-2011, the average cost of one year of undergraduate full-time studies at a 4-year institution was $\$ 22,092$ according to the U.S. National Center for Education Statistics (NCES). ${ }^{16}$ Given a GDP per capita of $\$ 49,800$ in 2011, the average costs of one year of college rack up to $44 \%$ of GDP per capita, which I target via the tuition cost $T$. The total expenditures of households on tertiary education sum up to $1.1 \%$ of total GDP according to the OECD (2011). Both private early education and college expenditures form the targets for the parameters determining the level $\phi_{0}$ and curvature $\phi_{1}$ of the altruism function. However, enrollment and private expenditures on tertiary education are not independent and enrollment is already targeted by $\psi_{0}$. Parents face a trade-off between saving for retirement, which is affected by the replacement rate, and investing in their children, which is affected by altruism. Therefore, I add the replacement rate, which households vote on, as an additional target for the altruism parameters to improve identification by having three targets for two parameters.

The share of students receiving federal grants is retrieved from the 2011 Digest of Education Statistics. ${ }^{17}$ Of all full-time undergraduate students, $64 \%$ received financial aid through grants in 2007-2008, which pins down $\kappa_{1}$, the parameter determining the slope of the college subsidy with respect to parental earnings. Parameter $\kappa_{0}$ does not require a target as it results as a residual from equation (4).

\subsubsection{Education decisions and outcomes}

In $2009,71 \%$ of high school graduates enrolled into college according to the National Science Foundation. ${ }^{18}$ Given a high school completion rate of $88 \%$ (Heckman and LaFontaine 2010), this results in a college enrollment rate of $62 \%$. Of all first-time, full-time students who enrolled at a 4-year institution in fall 2004, $58 \%$ completed college according to the NCES. ${ }^{19}$ The enrollment and completion rates serve as targets for the level and curvature parameters of the probability of college completion, $\psi_{0}$ and $\psi_{1}$.

\footnotetext{
${ }^{15}$ I restrict the sample to parents aged 32-48 with two children aged 6-17 and include expenditures on education, health, and other miscellaneous goods and services for children, such as games and instruments.

${ }^{16}$ For more information, see the website http://nces.ed.gov/fastfacts/display.asp? $i d=76$.

${ }^{17}$ See http://nces.ed.gov/programs/digest/d11/tables/dt11_353.asp.

${ }^{18}$ See http://www.nsf.gov/statistics/seind12/c1/c1s4.htm.

${ }^{19}$ See http://nces.ed.gov/fastfacts/display. asp?id=40.
} 
I use the 2011 IPUMS to calculate the college completion and dropout premium. The ratio of the average earnings of men aged 33 to 48 with at least four years of college education to those with no college education is 2.53 , while the ratio of those with less than four years of college to those with no college education is 1.32. These are targeted in the model by the college completion and dropout premium $\bar{\theta}$ and $\underline{\theta}$, respectively.

\subsubsection{Earnings}

The empirical estimation of the IEE was pioneered by Solon (1992) and Zimmerman (1992), who find a persistence of 0.4 in the US. ${ }^{20}$ This coefficient is targeted by the parameter for the intergenerational transmission of innate ability $\rho$, the coefficient of the autoregressive process. The variance of the random shock in the transmission of innate ability $\sigma_{a}$ is linked to the variance of log hourly wages of males. In the US, the variance of log hourly wages of males was 0.47 in 2005 (Heathcote et al. 2010). The Gini coefficient of hourly male wages in the US, my measure for earnings inequality, was 0.39 in 2005 (Heathcote et al. 2010). This is targeted by $\delta$, the parameter in charge of the level effect of human capital creation at the early stage. The relevant moment for the variance of the post-education earnings shock $\zeta$ is the share of the variance in earnings which is not explained by education and ability when entering the labor market for the first time. This share is 0.39 according to Huggett et al. (2011).

\subsubsection{Retirement}

The replacement rate for a median earner in the US averages $41 \%$ (OECD $2013 b)$. In the model, the replacement rate $\xi$ is determined through voting on the tax rate $\tau_{p}$. This endogenous outcome serves as an additional target for the altruism parameters $\phi_{0}$ and $\phi_{1}$ as outlined in Section 5.2.1.

\footnotetext{
${ }^{20}$ Concerning other estimates of intergenerational mobility, see Solon (1999) and Corak (2013b) for surveys of cross-country estimates, and Black and Devereux (2011) for an excellent overview of recent findings.
} 


\begin{tabular}{|c|c|c|c|c|}
\hline \multirow[b]{2}{*}{ Description } & \multicolumn{4}{|c|}{ Exogenously chosen } \\
\hline & Parameter & \multicolumn{3}{|c|}{ Value Reference } \\
\hline Coefficient of rel. risk aversion & $\sigma$ & 1.5 & Standard & \\
\hline Discount factor & $\beta$ & 0.96 & Standard & \\
\hline Consumption eq. scale & $\chi$ & 1.4 & OECD modified equivalence sca & ale \\
\hline Interest rate & $r$ & 0.011 & 3-month T-bill (1947-2008) & \\
\hline Time for college completion & $\bar{v}$ & 4 years & s Standard & \\
\hline Time for college dropout & $\underline{v}$ & 2 years & s Stinebrickner \& Stinebrickner 2 & 2008 \\
\hline Lifecycle wage premium & $\overline{\eta_{0}}$ & 1.8 & IPUMS 2011 & \\
\hline Lifecycle wage premium & $\eta_{1}$ & 1.1 & IPUMS 2011 & \\
\hline Tax spent on social exp. & $\tau_{s}$ & 0.19 & OECD 2012-2014 & \\
\hline Tax spent on college grants & $\tau_{q}$ & 0.002 & CBO 2011-2012 & \\
\hline \multirow[t]{2}{*}{ Voting weights $i \in\{o c, y, o p, r\}$} & $\omega_{i}$ & Table 1 & 1 CPS voting supplement 2006 & \\
\hline & \multicolumn{2}{|c|}{ Calibrated } & & \\
\hline Description & Parameter & Value $\mathrm{T}$ & Target & Data \\
\hline Elasticity wrt early education & $\gamma$ & $0.29 \mathrm{P}$ & Public early education/GDP & 0.035 \\
\hline Tuition cost per period & $\mathrm{T}$ & $0.16 \mathrm{~A}$ & Annual tuition costs/GDP per cap. & 0.44 \\
\hline Slope college sub. wrt earnings & $\kappa_{1}$ & $0.015 \mathrm{~S}$ & Share college students with grant & 0.64 \\
\hline Intercept college subsidy & $\kappa_{0}$ & $0.54 \mathrm{D}$ & Determined as resid. in equation (4) & \\
\hline Altruism & $\phi_{0}$ & $1.1 \mathrm{P}$ & Private early exp./earnings & 0.085 \\
\hline \multirow[t]{2}{*}{ Altruism curvature } & $\phi_{1}$ & 0.6 & Private college expenditure/GDP & 0.011 \\
\hline & & $0.41 \mathrm{R}$ & Replacement rate & 0.41 \\
\hline College completion wrt ability & $\psi_{0}$ & $0.23 \mathrm{~F}$ & Fraction attending college & 0.62 \\
\hline College completion wrt ability & $\psi_{1}$ & $1.02 \mathrm{C}$ & College completion rate & 0.58 \\
\hline College completion premium & $\bar{\theta}$ & $1.25 \mathrm{~A}$ & Average college premium & 2.53 \\
\hline College dropout premium & $\underline{\theta}$ & $0.88 \mathrm{~A}$ & Average dropout premium & 1.32 \\
\hline Level effect of HC prod. func. & $\bar{\delta}$ & $1.6 \mathrm{G}$ & Gini before tax & 0.39 \\
\hline Persistence ability transmission & $\rho$ & 0.2 & IEE & 0.40 \\
\hline STD of noise in ability trans. & $\sigma_{a}$ & $0.50 \mathrm{~V}$ & Variance of log hourly wages & 0.47 \\
\hline STD market luck shock & $\sigma_{\zeta}$ & $0.275 \mathrm{~S}$ & Share earnings variance post-educ. & 0.39 \\
\hline
\end{tabular}

Table 2: Benchmark model parameters

Notes: The calibrated parameter values are the result of a simulated minimum-distance estimator with a diagonal weighting matrix. 


\section{Benchmark economy}

In the following, I discuss the performance of the benchmark model in terms of replication of the US economy and identification of the jointly calibrated parameters. Generally speaking, the model performs well at replicating inequality in terms of the Gini, earnings persistence in terms of the IEE, the replacement rate, the fraction of individuals going to college, the dropout rate, and the tuition costs of one year of college relative to GDP per capita, as can be seen in Table 3 . The average college and dropout premium, as well as the share of college students receiving federal grants, are overestimated. The chosen rates for $\left(\tau_{g}, \tau_{p}, \kappa_{1}\right)$ are $(0.041,0.1558,0.015)$.

\begin{tabular}{lcc}
\hline \hline Target & Data & Model \\
\hline Intergenerational earnings elasticity & .40 & .38 \\
Gini before tax & .39 & .37 \\
Variance of log wages & .47 & .48 \\
Share of earnings variance post-schooling & .39 & .23 \\
Private early education exp./Mean earnings & .089 & .103 \\
Annual tuition costs/GDP per capita & .44 & .41 \\
Private college expenditure/GDP & .011 & .003 \\
Fraction attending college & .62 & .56 \\
College completion rate & .58 & .67 \\
Average college premium & 2.53 & 3.44 \\
Average dropout premium & 1.32 & 1.93 \\
Voting outcome & & \\
Public early education exp./GDP & .039 & .041 \\
Share of college students with grants & .64 & 1 \\
Replacement rate & .41 & .37 \\
\hline \hline
\end{tabular}

Table 3: Calibration of the US economy

Notes: The model moments are generated using a simulated minimum-distance estimator with a diagonal weighting matrix.

The share of the variance not explained by ability in the model is 0.23 , which is largely attributable to the idiosyncratic earnings shock experienced when transitioning into parenthood. Huggett et al. (2011) estimate this share to be 0.39, whereas Keane and Wolpin (1997) find that exogenous shocks to skills after the age of 16 account for only $10 \%$ of the variation. Therefore, the variation implied 
by the model lies in between these two prominent estimates. Both of the parameters governing the "genetic" ability transmission are not directly observed in the data. $^{21}$ Therefore, they are linked to two adulthood outcomes. The variance of log wages is also subject to the idiosyncratic earnings shock, but its main driver is the variance of the shock experienced in the ability transmission from parents to children, as $\sigma_{a}$ is responsible for the dispersion of the underlying ability of the model economy. The model replicates the dispersion of earnings observed in the data very closely. The correlation in innate ability $\rho$ is 0.2 , which is identified through the intergenerational elasticity of earnings holding public and private education fixed. A large part of the earnings persistence in the model (0.38) arises due to the underlying structure, i.e. through parental investments.

Holding the amount of public expenditures and the elasticity of returns to investment fixed, early education expenditures are subject to the amount of altruism parents feel for their children. However, given that altruism is governed by two parameters and also affects investments in college, the identification of the parameters requires at least one additional target related to college investments as discussed in Section 5.2.1. In the benchmark economy, parents value the human capital of their children with $\phi_{0}=1.1$ and curvature $\phi_{1}=0.6$, i.e. at a high level with decreasing returns. Concerning the targets, the resulting replacement rate is slightly lower than in the data at 0.37 , while parents underinvest privately into college, partially due to the lower enrollment rate than is observed in the data. At the same time, parents overinvest slightly into their children at the earlier stage by sacrificing $10.4 \%$ of their earnings compared to $8.9 \%$ in the data.

Holding altruism and the level of private early education expenditures fixed, the amount of public expenditures society votes for should largely be attributable to the effectiveness of early education. In the benchmark, public early education investments account for $4.1 \%$ of GDP, which is slightly higher than the $3.9 \%$ in the data. This can be attributed to the relatively high elasticity of returns to early education investments $(\gamma=0.29)$, which is comparable to estimates for both public and private investments. Agostinelli and Wiswall (2016) and Boneva and Rauh (2016) find the elasticity of cognitive skills with respect to parental time investments over the course of childhood to average 0.19 and 0.24 , respectively. Both studies estimate a dynamic latent factor model with micro-level panel data using a comparable specification for skill accumulation as in equation (2). For

\footnotetext{
${ }^{21}$ Attempts to estimate the genetic transmission of ability have not yet been able to separate nature from nurture convincingly.
} 
public expenditures, Card and Krueger $(1992,1996)$ estimate an elasticity of about 0.2 . The parameter of the early education production function responsible for the level effect of investments is $\delta$, which takes the value 1.6, and is identified through the resulting Gini index of earnings. The higher the level of $\delta$, the higher are incentives to invest in early education, in particular for children expected to graduate from college in the future. Therefore, $\delta$ plays an important role for the level of inequality a society experiences.

Identifying the college premium parameter is particularly challenging and has been studied through a range of IV (e.g., Card 1993) and structural estimation strategies (e.g., Heckman et al. 2006, Carneiro et al. 2011, Heckman et al. 2016). The observed college premium consists of two components: first, the causal effect of graduating from college; second, positive selection into college in terms of ability. The calibration settles on a college premium parameter $\bar{\theta}$ of 1.25 . Given that it is multiplied with acquired ability, the observed average college premium is $3.44,36 \%$ higher than in the data. ${ }^{22}$ Heckman et al. (2016) find causal returns to college graduation in the range of 17.1-26.9\% when using structural models or propensity matching, which suggests that the $25 \%$ resulting from the calibration lies within the plausible range of estimates. The difficulty of matching enrollment and selection into college can in part be attributed to the missing consumption value or psychic cost of college in the model, which has been identified as an important driver of the decision to enroll in college in structural models (e.g., Heckman et al. 2006, Carneiro et al. 2011) and using survey data (Belfield et al. 2016). The college dropout parameter $\underline{\theta}$ is 0.88 . The fact that the dropout premium is smaller than unity can be interpreted in terms of a negative signal in the labour market associated with dropping out or lost time that could have been spent learning on the job and acquiring experience in the labor market.

The voted college subsidy parameters $\kappa_{0}$ and $\kappa_{1}$ provide a rather flat subsidy schedule, which benefits all enrolled students, in contrast to the $64 \%$ of students who benefit in the data. This can be attributed to the fact that both enrollment and turnout are skewed towards the educated, who would not profit from a steeper schedule.

\footnotetext{
${ }^{22}$ When using the CPS March supplement of 2011 and correcting for top-coded earnings by fitting a Pareto distribution to the top 20\%, the college (dropout) premium increases to 2.74 (1.55). According to this metric, the college premium in the model is only $25 \%$ above the data moment. Moreover, Armour et al. (2016) show that top incomes are underestimated even when using this correction method.
} 


\subsection{Voting experiments in the US}

In the following, I conduct a range of voting experiments for the US by adjusting voting weights. ${ }^{23}$ For each counterfactual simulation, I compute the steady state when households vote on $\left(\tau_{g}, \tau_{p}, \kappa_{1}\right)$ with the respective voting weights while adapting their economic decisions accordingly. All non-voted parameters are held fixed. The results are summarized in Table 6 in which the first and third columns display the outcomes for IEE and Gini, respectively, while the second and fourth columns exhibit the relative changes compared to the benchmark economy.

Voter turnout in the US is lower and more skewed towards the educated than in most OECD countries. Therefore, one possible policy to counter this could be compulsory voting, as already exists in a number of countries (e.g., Argentina, Australia, Brazil, Peru). I simulate the policy experiment by imposing mandatory voting for all. In technical terms, this means that for all $b$ we have $\omega_{j}(b)=1$ for $j \in\{y, o p, r\}$ and $\omega_{o c}(b)=0.875$. If everybody were to cast their vote, public education funding of early education would increase from $4.1 \%$ to $5.7 \%$ of GDP and financial aid would be directed more at poorer households. As a consequence, the Gini reduces marginally by $4 \%$, earnings persistence drops by $17 \%$, and aggregate consumption increases by $9.7 \% .{ }^{24}$ When people with lower education, who are on average also poorer, are more likely to turn out, the demand for public early education increases. Now that more children from poorer backgrounds are better prepared for college, they enroll in college at higher rates, thereby also broadening support for college subsidies for the poor, which further lowers financial barriers of entry to college. This boost in enrollment from poorer households feeds back into the demand for public early education due to the dynamic complementarity. The combination of these effects is what makes a child's education, and therefore earnings, less dependent on parental earnings.

Two policies which have recently received attention in the public debate, are the extension of the electoral franchise to children as of birth and reducing the

\footnotetext{
${ }^{23}$ The voting mechanism, probabilistic voting, is chosen out of pragmatic reasons due to the complexity and heterogeneity of the overlapping generations model. Interesting voting extensions would include comparing proportional representation, majority voting, or first-past-the-post voting. However, within the chosen framework, these voting systems cannot be compared in a straightforward manner and are left for future work.

${ }^{24}$ This is not to claim that these changes would be immediate, as politicians would naturally take time to identify preferences of the electorate, which would take several elections. Also, I am assuming the implementation to be costless, thereby ignoring monitoring costs.
} 
voting age to $16 .^{25}$ For both experiments, I multiply the component of $\omega_{o}(b)$ that is attributable to the children by 1 instead of $7 / 8$. To simulate the extension of electoral franchise to children as of birth, in addition, I double the benchmark voting weight $\omega_{y}(b)$ of young parent households. I assume no changes in terms of the relative likelihood of turnout. ${ }^{26}$ As a result of letting parents vote for their children, inequality reduces to a Gini of 0.34 , whereas intergenerational mobility surges due to increases in public early education expenditures, thus reducing earnings persistence to 0.29 . The effects are much larger than for compulsory voting as young parents face tighter budget constraints and their large weight in the political process leads to high early education expenditures. Reducing the legal voting age to 16 decreases the IEE by $8 \%$, while the effect on pre-tax inequality is negligible.

Finally, I replace the lump-sum education expenditure by a proportional subsidy for early education, i.e. the government covers a fraction of private expenditures. Abbott and Gallipoli (2017) show analytically that in their setting only lump-sum education expenditures affect earnings persistence. Under the simulated alternative, public expenditures drop close to zero with the consequence of an increase in earnings persistence to an IEE of 0.44 and a reduction of aggregate consumption by more than $2 \%$.

\subsection{Exogenous changes in earnings shocks}

In order to gain an understanding of whether inequality and mobility are mechanically related in the model, I run experiments with exogenous changes to $\sigma_{\zeta}$, the standard deviation of the earnings shock. When $\sigma_{\zeta}$ is reduced by $50 \%$, I find that the Gini drops to 0.32, while the IEE actually increases to 0.41. Conversely, an increase of $50 \%$ in $\sigma_{\zeta}$ leads to a benign rise in the Gini, while the IEE declines to 0.26 . Hence, the experiment reveals a negative relationship between inequality and earnings persistence. The intuition behind the result is that when the variance

\footnotetext{
${ }^{25}$ The extension of franchise to children is commonly referred to as "Demeny voting", named after Paul Demeny, the author of a paper suggesting half a vote for children to counter low fertility (Demeny 1986). See, for example, http://www.nytimes.com/2013/03/08/ world/americas/08iht-letter08.html?_r=1\& or http://milescorak.com/2013/06/ 02/should-children-be-given-the-vote-watch-this-tedx-talk/ for recent discussions. The practical implementation discussed would include parents voting for their children.

${ }^{26}$ This is debatable given that an increased voting weight raises incentives to vote, which thus could feedback into turnout of the treated group as well. Given that voters are atomistic and turnout is not modeled in the framework, I refrain from speculating about the magnitude of the possible increase in turnout among young parents.
} 
of the earnings shock decreases (increases), the link between parental investments and future earnings becomes tighter (looser). ${ }^{27}$

\section{Cross-country differences}

As visible in the "Great Gatsby Curve", inequality and intergenerational mobility are negatively associated across countries. In order to identify potential drivers of this relationship, I conduct experiments exploiting cross-country differences in voter turnout.

\subsection{Voter turnout}

Voter turnout shows strong variations by age and levels of education across countries. There is a strand of literature attempting to explain cross-country differences in voter turnout and specifically low turnout in the US (e.g., Wolfinger and Rosenstone 1980, Powell Jr 1986, Jackman 1987, Blais 2000, Perea 2002). General explanations for cross-country differences include legal differences, such as compulsory voting or voting facilitation through postal or advanced voting, organizational factors and electoral systems, such as number of parties, party-group alignment, and proportional representation, and population size. Concerning the US, there seems to be consensus that the complexity of registration is one reason for low turnout amongst poorer individuals. While the exogeneity of voter turnout might be debatable, this experiment can be interpreted as relying on the exogeneity of the aforementioned costs and institutions driving differential turnout patterns. ${ }^{28}$ I use this variation to adjust voting weights in the probabilistic voting process and explain variation in earnings inequality and the IEE. Voter turnout

\footnotetext{
${ }^{27}$ In a previous version of the paper, I look at the effect of differences in the exogenous component of the college premium and find a positive relation between inequality and earnings persistence. The results suggest that increases in inequality in the top half of the earnings distribution, rather than increases in inequality per se, are indeed related to increases in earnings persistence. Note that this result is subject to the model assumption that parents value children's human capital rather than future earnings as a change in $\sigma_{\zeta}$, ceteris paribus, does not affect investment incentives, whereas a change in $\bar{\theta}$ does.

${ }^{28}$ Fujiwara (2015) uses the introduction of electronic voting in Brazil, which reduces invalid votes by the poor, to show how the exogenous change in voter composition affects pro-poor policies (which in the studied case manifests itself in the form of increased expenditures on child health). Similar changes could take place if voting costs that disproportionately affect the poor in the US, such as early registration or the presentation of a birth certificate, were removed.
} 
by age group and education is determined using the 2010 European Social Survey for European countries and the 2010 Canadian Election Study for Canada, as displayed in Appendix Table 7. I assign these weights to the respective age groups and education levels in the probabilistic voting mechanism of the benchmark model, while leaving all other parameters fixed (except for those determined through voting).

I find that voter turnout alone explains $31 \%$ of the variation in the Gini and $27 \%$ of the variation in the IEE. ${ }^{29}$ The share of the gap between a data moment in the US $d_{U S}$ and another country $d_{\text {country }}$ explained by moments $m_{\text {country }}$ produced by the model, is defined as $\frac{\left(m_{U S}-m_{\text {country }}\right)}{\left(d_{U S}-d_{\text {country }}\right)}$. The results are summarized in Table 4, in which I present the data and model moments of the IEE and the gap explained in the first three columns followed by the same information for the Gini. Figure 3 shows that the experiment replicates the negative relationship between inequality (x-axis) and non-tertiary public education expenditures (y-axis), while Figure 4 displays the replication of the "Great Gatsby Curve", i.e. the positive relationship between inequality (x-axis) and IEE (y-axis) generated by the model (in gray) compared to the data (in black). While the patterns are replicated nicely, for the explained gap between the US and other countries, we see mixed results. On the one hand, the simulated IEE for other countries is always smaller than in the US, as is the case in the data. On the other hand, for income inequality in some countries we observe an increase, which in terms of the data, though belonging to the set of relatively unequal countries, exhibit lower inequality levels than the US.

Canada has a Gini of 0.37 (OECD 2013a) and a relatively low earnings persistence of 0.21 (Corak 2013a). Voter turnout patterns are capable of explaining $13 \%$ of the difference in earnings persistence to the US, but inequality is larger than in the US in the simulation. In the UK, the Gini of individual earnings is 0.383 (OECD 2013a), while the IEE is estimated to be 0.31 (Jäntti et al. 2006). Voter turnout is increasing in age and education in the UK. However, the bias is relatively lower than in the US, leading to a very small reduction in earnings persistence, but a slight increase in inequality.

\footnotetext{
${ }^{29}$ These values are the $R^{2}$ of an OLS regression with the data moments on the LHS and the model moments plus a constant on the RHS. The US is excluded from this regression as the model is calibrated to replicate the US.
} 


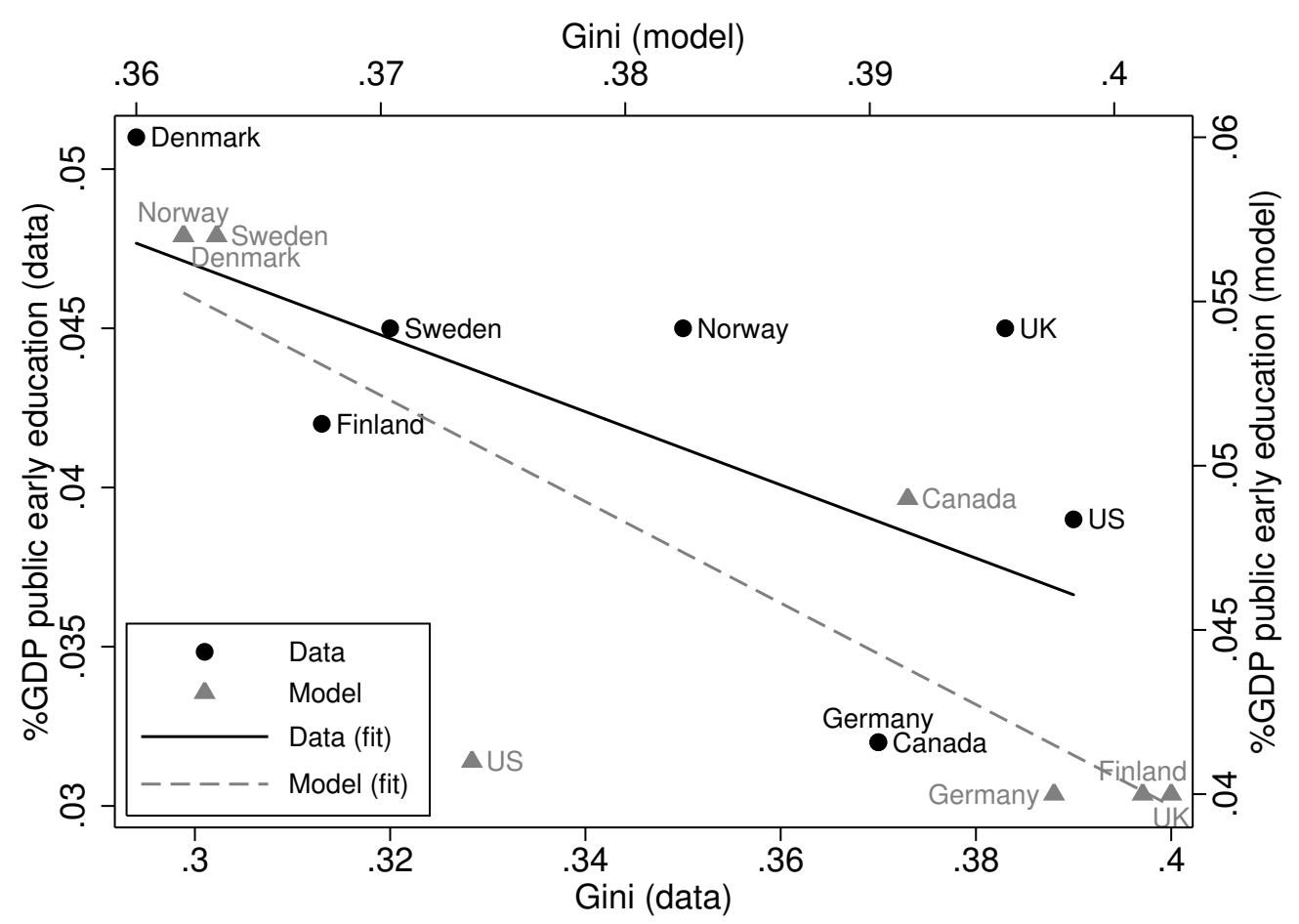

Figure 3: Inequality versus public non-tertiary education expenditures (data versus voting experiment)

Data source: Gini from OECD (2013a); education expenditures from OECD (2011).

Notes: The figure compares model moments with country-specific voter turnout by age and education (gray) and data moments (black) of the earnings Gini before taxes and transfers (x-axis) versus public expenditures (\% of GDP) on non-tertiary education (y-axis). The black solid line represents a linear fit of the data moments, while the gray dashed line represents a linear fit of model moments. The bottom $\mathrm{x}$-axis and left $\mathrm{y}$-axis refer to the data moments, while the top $\mathrm{x}$-axis and right $y$-axis refer to the model moments.

Denmark is among the most equal countries and has the lowest IEE in both the data and the model. The Gini of individual pre-tax earnings is estimated to be 0.294 (OECD 2013a), while the IEE is 0.15 (Corak 2013a). In Denmark, voter turnout is relatively high across all age groups and levels of education, resulting in a simulated Gini of 0.36 and an IEE of 0.32 , accounting for $12 \%$ and $23 \%$ of the gaps, respectively. Norway has a similarly low level of earnings persistence of 0.17 (Corak 2013a) and a Gini of 0.35 (OECD 2013a). In Norway, voter turnout explains $29 \%$ of the difference in inequality and $25 \%$ of the difference in earn- 
ings persistence. Finland follows the pattern of the other Scandinavian countries with a pre-tax earnings Gini of 0.31 (OECD 2013a) and an IEE of 0.18 (Corak 2013a). For the case of Finland, however, voter turnout cannot explain the gaps in inequality and mobility.

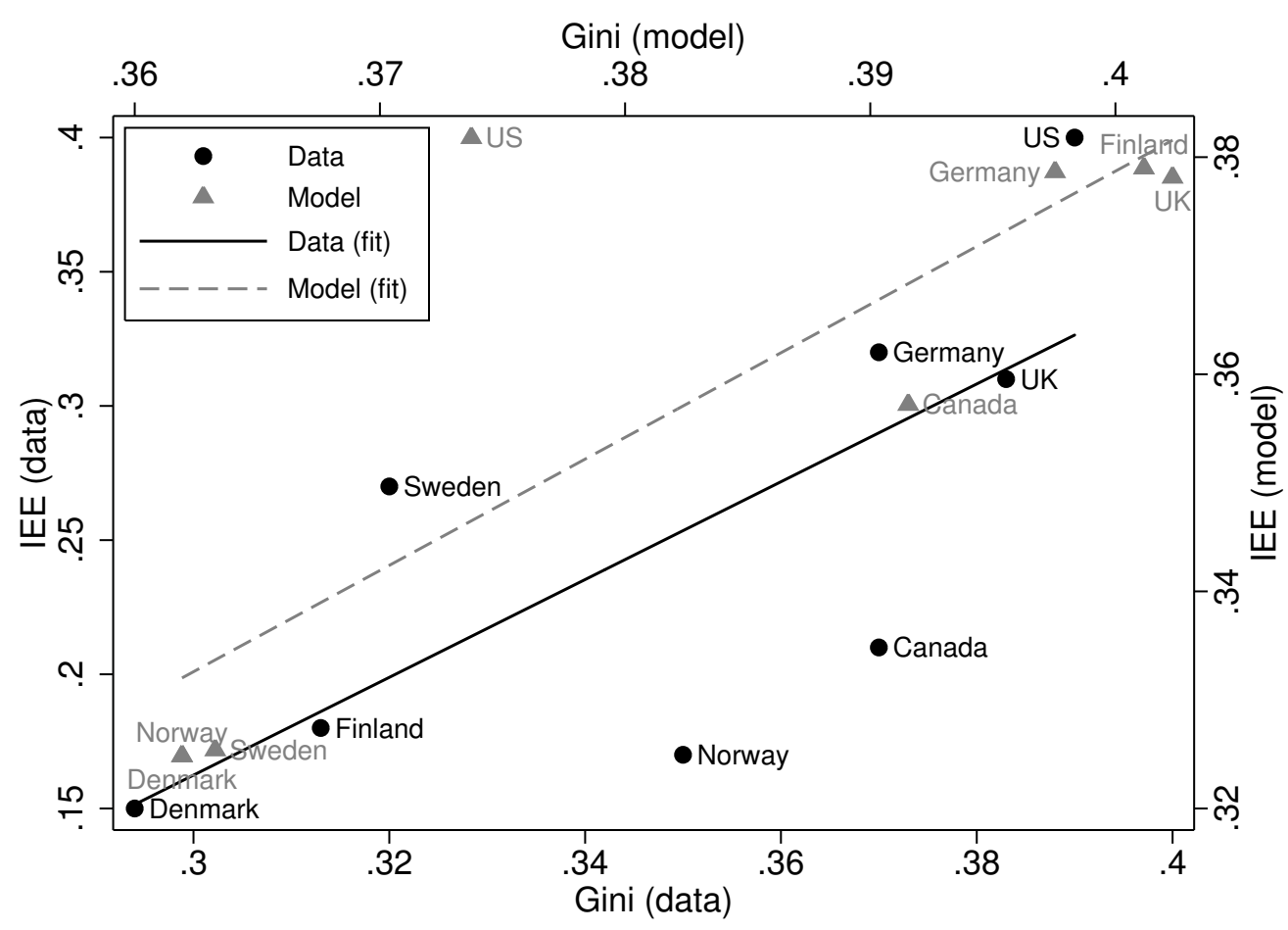

Figure 4: Inequality versus intergenerational earnings persistence (data versus voting experiment)

Data source: See Section 7.1.

Notes: The figure compares model moments with country-specific voter turnout by age and education (gray) and data moments (black) of the earnings Gini before taxes and transfers (x-axis) versus IEE (y-axis). The black solid line represents a linear fit of the data moments, while the gray dashed line represents a linear fit of model moments. The bottom $x$-axis and left $y$-axis refer to the data moments, while the top $\mathrm{x}$-axis and right $\mathrm{y}$-axis refer to the model moments.

In Germany, the pre-tax earnings Gini is estimated to be 0.37 (Fuchs-Schündeln et al. 2010) and the IEE is 0.32 (Corak 2013a). Both values are in the middle of the distribution of OECD countries. Voting participation in Germany is biased towards the older and more educated, but not to such an extreme extent as in the 
US. The publicly chosen education expenditures as well as the Gini and the IEE are in the middle range of the simulations, not explaining much of the gaps.

Sweden is characterized by a low earnings persistence of 0.27 (Corak 2013a) and a pre-tax Gini of individual earnings of 0.32 (Domeij and Floden 2010). ${ }^{30}$ Swedes of all age groups are equally likely to vote, and voter turnout is not biased towards the highly educated as in the US. The resulting higher levels of chosen public education funding reduce the IEE by $10 \%$ to 0.35 and the Gini to 0.37 . Thereby, voter turnout can explain $43 \%$ and $15 \%$ of the gaps between Sweden and the US in earnings persistence and inequality, respectively. These improvements in inter- and intragenerational equity are accompanied by a nearly $10 \%$ increase in aggregate consumption, thereby not providing evidence on an equity-efficiency tradeoff. In Sweden, inequality increased over the 90's, but to a lesser extent than in the US. Similarly, intergenerational mobility remains high despite increases in earnings inequality. The model indicates that the political economy, and more specifically voter participation, might be one reason why the increase in the skill premium in the 90's might have had a less harsh effect on inequality and mobility in Sweden than in the US.

\footnotetext{
${ }^{30}$ While Gini values in the introduction are from the OECD in order to maximize sample size, in my detailed analysis most estimates stem from a special edition of the Review of Economic Dynamics, in which comparable data and methodology are used for a range of countries. The patterns are very similar for both sets of estimates.
} 


\begin{tabular}{lccccccc}
\hline \hline & \multicolumn{3}{c}{ Intergenerational elasticity } & & \multicolumn{3}{c}{ Gini } \\
\cline { 2 - 3 } \cline { 6 - 7 } Country & Data & Model & $\Delta_{\text {explained }}$ & & Data & Model & $\Delta_{\text {explained }}$ \\
\hline US & .40 & .382 & & & .39 & .373 & \\
Canada & .21 & .357 & .13 & & .37 & .392 & -.89 \\
Denmark & .15 & .324 & .23 & & .294 & .362 & .12 \\
Finland & .18 & .379 & .01 & & .313 & .401 & -.36 \\
Germany & .32 & .378 & .04 & & .37 & .398 & -1.19 \\
Norway & .17 & .325 & .25 & & .35 & .362 & .29 \\
Sweden & .27 & .325 & .43 & & .32 & .363 & .15 \\
UK & .31 & .378 & .04 & & .383 & .402 & -4.09 \\
\hline \hline
\end{tabular}

Table 4: Counterfactuals (voter turnout)

Notes: The share of the gap between a data moment in the US $d_{U S}$ and another country $d_{\text {country }}$ explained by moments $m_{\text {country }}$ and $m_{U S}$ produced by the model, is calculated using: $\Delta=\frac{\left(m_{U S}-m_{\text {country }}\right)}{\left(d_{U S}-d_{\text {country }}\right)}$.

\section{Robustness check using party membership}

The educated are more likely to participate in a range of political activities such as signing petitions, attending meetings, writing to Congress, or contributing to campaigns (Schlozman and Brady 2012). As a robustness check to the voter turnout experiment, I instead use variations in political party membership. Party members spread political propaganda, mobilize voters, and form and shape agendas (Huckfeldt and Sprague 1992, Green and Gerber 2008). Ichino et al. (2011) find that across countries, intergenerational mobility is positively associated with party membership of the poor relative to the rich. I use the first, third, and fifth wave of the World Values Survey to determine the membership rate (active as well as inactive) by age group and level of education in order to assign these shares as weights, as displayed in Appendix Table 7, in the probabilistic voting process.

In the US, the share of individuals that are active or inactive members of a political party is highest among the countries examined. However, once again participation is biased towards the older and more educated. Similarly, the bias in most other countries is not as pronounced. In Appendix Figure 5, the data moments (black) are contrasted with the model moments (gray) in terms of inequality (x-axis) versus intergenerational earnings persistence (y-axis). One can tell that the "Great Gatsby Curve" is again replicated by the experiment, leaving the results qualitatively unchanged. 


\section{Conclusions}

I calibrate a model characterized by dynamic complementarity between early and college education to the US economy. Households vote on the level and allocation of education expenditures in non-tertiary and tertiary education, as well as on a public pension and redistribution. The model performs well at replicating the US economy across several dimensions including inequality, intergenerational mobility, the share of GDP dedicated to early education, and the replacement rate of the public pension.

When taking into account country-specific voter turnout by age and level of education in the probabilistic voting process, the negative association between inequality and public expenditures on education observed in cross-country data is reconciled. Political participation in the form of voter turnout explains more than one quarter of the variation in earnings inequality and intergenerational persistence when comparing the US to Canada, Denmark, Finland, Germany, Norway, Sweden, and the UK. Assigning voting weights according to party membership instead of voter turnout leaves the results qualitatively unchanged.

Concerning voting policies in the US, I find that compulsory voting or extending the electoral franchise to children as of birth by letting their parents vote on their behalf would reduce the share of earnings transmitted across generations substantially. However, the effects of these policies on pre-tax inequality are found to be comparably weak.

The variation of IEE within the US, as exhibited in Chetty et al. (2014), and the exclusion of pre-primary education in the model provide fruitful areas for future research.

\section{References}

Abbott, B., Gallipoli, G., 2017. Skill complementarity and the geography of intergenerational mobility. Review of Economic Dynamics 24.

Abbott, B., Gallipoli, G., Meghir, C., Violante, G. L., 2013. Education policy and intergenerational transfers in equilibrium. National Bureau of Economic Research.

Agostinelli, F., Wiswall, M., 2016. Estimating the technology of children's skill formation. National Bureau of Economic Research.

Armour, P., Burkhauser, R. V., Larrimore, J., 2016. Using the pareto distribution to improve estimates of topcoded earnings. Economic Inquiry 54 (2), 1263-1273. 
Becker, G. S., Tomes, N., 1979. An equilibrium theory of the distribution of income and intergenerational mobility. Journal of Political Economy, 1153-1189.

Becker, G. S., Tomes, N., 1986. Human capital and the rise and fall of families. Journal of Labor Economics 4 (1).

Belfield, C., Boneva, T., Rauh, C., Shaw, J., 2016. Money or fun? Why students want to pursue further education. IZA Discussion Paper.

Belley, P., Frenette, M., Lochner, L., 2014. Post-secondary attendance by parental income in the US and Canada: Do financial aid policies explain the differences? Canadian Journal of Economics/Revue canadienne d'économique 47 (2), 664696.

Benabou, R., 2000. Unequal societies: Income distribution and the social contract. American Economic Review, 96-129.

Björklund, A., Eriksson, T., Jäntti, M., Rauum, O., Österbacka, E., 2004. Family structure and labour market success: the influence of siblings and birth order on the earnings of young adults in Norway, Finland and Sweden. In: Corak, M. (Ed.), Generational Income Mobility in North America and Europe. Cambridge University Press, Ch. 9, pp. 207-225.

Black, S. E., Devereux, P. J., 2011. Recent developments in intergenerational mobility. In: Card, D., Ashenfelter, O. (Eds.), Handbook of Labor Economics. Vol. 4. Elsevier, pp. 1487-1541.

Blais, A., 2000. To vote or not to vote?: The merits and limits of rational choice theory. University of Pittsburgh Press.

Boneva, T., Rauh, C., 2016. Human capital production and parental beliefs. Mimeo.

Bonica, A., McCarty, N., Poole, K. T., Rosenthal, H., 2013. Why hasn't democracy slowed rising inequality? Journal of Economic Perspectives 27 (3), 103123.

Busemeyer, M. R., 2012. Inequality and the political economy of education: An analysis of individual preferences in OECD countries. Journal of European Social Policy 22 (3), 219-240. 
Card, D., 1993. Using geographic variation in college proximity to estimate the return to schooling. National Bureau of Economic Research.

Card, D., Krueger, A. B., 1992. Does school quality matter? Returns to education and the characteristics of public schools in the United States. Journal of Political Economy 100 (1), 1-40.

Card, D., Krueger, A. B., 1996. School resources and student outcomes: An overview of the literature and new evidence from North and South Carolina. Journal of Economic Perspectives 10 (4), 31-50.

Carneiro, P., Heckman, J. J., Vytlacil, E. J., 2011. Estimating marginal returns to education. American Economic Review 101, 2754-2781.

Caucutt, E. M., Lochner, L., 2012. Early and late human capital investments, borrowing constraints, and the family. National Bureau of Economic Research.

Chatterjee, S., Ionescu, F., 2012. Insuring student loans against the financial risk of failing to complete college. Quantitative Economics 3 (3), 393-420.

Chetty, R., Hendren, N., Kline, P., Saez, E., 2014. Where is the land of opportunity? The geography of intergenerational mobility in the United States. The Quarterly Journal of Economics 129 (4), 141-147.

Chong, A., Olivera, M., 2008. Does compulsory voting help equalize incomes? Economics \& Politics 20 (3), 391-415.

Corak, M., 2013a. Income inequality, equality of opportunity, and intergenerational mobility. Journal of Economic Perspectives, 79-102.

Corak, M., 2013b. Inequality from generation to generation: The inequality from generation to generation: The United States in comparison. In: Rycroft, R. (Ed.), The Economics of Inequality, Poverty, and Discrimination in the 21st Century. Vol. 2. ABCCLIO, Oxford, England, pp. 107-126.

Corak, M., Piraino, P., 2011. The intergenerational transmission of employers. Journal of Labor Economics 29 (1), 37-68.

Cunha, F., Heckman, J. J., 2008. Formulating, identifying and estimating the technology of cognitive and noncognitive skill formation. Journal of Human Resources 43 (4), 738-782. 
Cunha, F., Heckman, J. J., Lochner, L., Masterov, D. V., 2006. Interpreting the evidence on life cycle skill formation. Handbook of the Economics of Education 1, 697-812.

Cunha, F., Heckman, J. J., Schennach, S. M., 2010. Estimating the technology of cognitive and noncognitive skill formation. Econometrica 78 (3), 883-931.

De la Croix, D., Doepke, M., 2004. Public versus private education when differential fertility matters. Journal of Development Economics 73 (2), 607-629.

De la Croix, D., Doepke, M., 2009. To segregate or to integrate: education politics and democracy. Review of Economic Studies 76 (2), 597-628.

Demeny, P., 1986. Pronatalist policies in low-fertility countries: Patterns, performance, and prospects. Population and Development Review, 335-358.

Domeij, D., Floden, M., 2010. Inequality trends in Sweden 1978-2004. Review of Economic Dynamics 13 (1), 179-208.

Duncan, G. J., Murnane, R. J., 2011. Whither opportunity?: Rising inequality, schools, and children's life chances. Russell Sage Foundation.

Fuchs-Schündeln, N., Krueger, D., Sommer, M., 2010. Inequality trends for Germany in the last two decades: A tale of two countries. Review of Economic Dynamics 13 (1), 103-132.

Fujiwara, T., 2015. Voting technology, political responsiveness, and infant health: evidence from Brazil. Econometrica 83 (2), 423-464.

Gilens, M., 2012. Affluence and influence: Economic inequality and political power in America. Princeton University Press.

Green, D. P., Gerber, A. S., 2008. Get out the vote: How to increase voter turnout. Brookings Institution Press.

Heathcote, J., Perri, F., Violante, G. L., 2010. Unequal we stand: An empirical analysis of economic inequality in the United States, 1967-2006. Review of Economic Dynamics 13 (1), 15-51.

Heckman, J. J., Humphries, J. E., Veramendi, G., 2016. Returns to education: The causal effects of education on earnings, health and smoking. National Bureau of Economic Research. 
Heckman, J. J., LaFontaine, P. A., 2010. The American high school graduation rate: Trends and levels. Review of Economics and Statistics 92 (2), 244-262.

Heckman, J. J., Lochner, L. J., Todd, P. E., 2006. Earnings functions, rates of return and treatment effects: The Mincer equation and beyond. Handbook of the Economics of Education 1, 307-458.

Herrington, C. M., 2015. Public education financing, earnings inequality, and intergenerational mobility. Review of Economic Dynamics 18 (4), 822-842.

Hettich, W., Winer, S., 1984. A positive model of tax structure. Journal of Public Economics 24 (1), 67-87.

Holter, H. A., 2015. Accounting for cross-country differences in intergenerational earnings persistence: The impact of taxation and public education expenditure. Quantitative Economics 6 (2), 385-428.

Huckfeldt, R., Sprague, J., 1992. Political parties and electoral mobilization: Political structure, social structure, and the party canvass. American Political Science Review 86 (01), 70-86.

Huggett, M., Ventura, G., Yaron, A., 2006. Human capital and earnings distribution dynamics. Journal of Monetary Economics 53 (2), 265-290.

Huggett, M., Ventura, G., Yaron, A., 2011. Sources of lifetime inequality. American Economic Review 101 (7), 2923-2954.

Ichino, A., Karabarbounis, L., Moretti, E., 2011. The political economy of intergenerational income mobility. Economic Inquiry 49 (1), 47-69.

Jackman, R. W., 1987. Political institutions and voter turnout in the industrial democracies. American Political Science Review, 405-423.

Jäntti, M., Bratsberg, B., Røed, K., Raaum, O., Naylor, R., Österbacka, E., Björklund, A., Eriksson, T., 2006. American exceptionalism in a new light: A comparison of intergenerational earnings mobility in the Nordic countries, the United Kingdom and the United States. Working Paper.

Keane, M. P., Wolpin, K. I., 1997. The career decisions of young men. Journal of Political Economy 105 (3), 473-522. 
Kornrich, S., Furstenberg, F., 2013. Investing in children: Changes in parental spending on children, 1972-2007. Demography 50 (1), 1-23.

Krueger, A., 2012. The rise and consequences of inequality. URL http://www.americanprogress.org/events/2012/01/12/17181/ the-rise-and-consequences-of-inequality

Light, A., Strayer, W., 2000. Determinants of college completion: School quality or student ability? Journal of Human Resources, 299-332.

Lijphart, A., 1997. Unequal participation: democracy's unresolved dilemma. American Political Science Review, 1-14.

Lindbeck, A., Weibull, J. W., 1987. Balanced-budget redistribution as the outcome of political competition. Public choice 52 (3), 273-297.

Lochner, L., Monge-Naranjo, A., 2012. Credit constraints in education. Annual Review of Economics 4 (1), 225-256.

Loury, G. C., 1981. Intergenerational transfers and the distribution of earnings. Econometrica, 843-867.

OECD, 2011. Education at a glance.

OECD, 2013a. Divided we stand: Why inequality keeps rising.

OECD, 2013b. Pensions at a glance 2013.

Perea, E. A., 2002. Individual characteristics, institutional incentives and electoral abstention in Western Europe. European Journal of Political Research 41 (5), 643-673.

Persson, T., Tabellini, G. E., 2002. Political economics: explaining economic policy. MIT press.

Powell Jr, G. B., 1986. American voter turnout in comparative perspective. American Political Science Review, 17-43.

Restuccia, D., Urrutia, C., 2004. Intergenerational persistence of earnings: The role of early and college education. American Economic Review, 1354-1378. 
Schlozman, K. L., Brady, H. E., 2012. The unheavenly chorus: Unequal political voice and the broken promise of American democracy. Princeton University Press.

Smith, T. W., Marsden, P., Hout, M., Kim, J., 2015. General Social Surveys, 19722014. NORC at the University of Chicago.

Solon, G., 1992. Intergenerational income mobility in the United States. American Economic Review, 393-408.

Solon, G., 1999. Intergenerational mobility in the labor market. Handbook of Labor Economics 3, 1761-1800.

Stinebrickner, R., Stinebrickner, T., 2008. The effect of credit constraints on the college drop-out decision: A direct approach using a new panel study. American Economic Review 98 (5), 2163-2184.

Wolfinger, R., Rosenstone, S., 1980. Who votes? Yale University Press.

Zimmerman, D. J., 1992. Regression toward mediocrity in economic stature. American Economic Review, 409-429.

\section{Appendix}

10.1. Tables and figures 


\begin{tabular}{|c|c|c|c|c|c|c|}
\hline \multirow[b]{2}{*}{ Age } & \multicolumn{3}{|c|}{ Congress } & \multicolumn{3}{|c|}{ President } \\
\hline & $\begin{array}{l}\text { High } \\
\text { school }\end{array}$ & $\begin{array}{l}\text { Some } \\
\text { college }\end{array}$ & College & $\begin{array}{l}\text { High } \\
\text { school }\end{array}$ & $\begin{array}{l}\text { Some } \\
\text { college }\end{array}$ & College \\
\hline & \multicolumn{3}{|c|}{1998} & \multicolumn{3}{|c|}{1996} \\
\hline $18-32$ & .16 & .28 & .41 & .28 & .47 & .66 \\
\hline $33-48$ & .32 & .49 & .63 & .45 & .65 & .79 \\
\hline $48-64$ & .47 & .66 & .73 & .59 & .76 & .86 \\
\hline \multirow[t]{2}{*}{$65-80$} & .58 & .77 & .83 & .67 & .83 & .85 \\
\hline & \multicolumn{3}{|c|}{2002} & \multicolumn{3}{|c|}{2000} \\
\hline $18-32$ & .15 & .26 & .44 & .29 & .47 & .67 \\
\hline $33-48$ & .33 & .50 & .64 & .47 & .65 & .79 \\
\hline $48-64$ & .46 & .61 & .76 & .58 & .75 & .84 \\
\hline \multirow[t]{2}{*}{$65-80$} & .56 & .75 & .79 & .65 & .81 & .88 \\
\hline & \multicolumn{3}{|c|}{2006} & \multicolumn{3}{|c|}{2004} \\
\hline $18-32$ & .17 & .29 & .46 & .35 & .58 & .72 \\
\hline $33-48$ & .32 & .48 & .64 & .50 & .69 & .82 \\
\hline $48-64$ & .47 & .63 & .77 & .60 & .78 & .85 \\
\hline $65-80$ & .58 & .73 & .80 & .66 & .83 & .86 \\
\hline
\end{tabular}

Table 5: Voting patterns US 1996-2006

Data source: CPS November voting supplement 1996-2006.

Notes: Age at time of election.

\begin{tabular}{lcclcc}
\hline \hline & \multicolumn{2}{c}{ Intergenerational elasticity } & & \multicolumn{2}{c}{ Gini } \\
\cline { 2 - 3 } \cline { 5 - 6 } Country & Model & \% change & & Model & \% change \\
\hline US benchmark & .382 & & & .373 & \\
Full turnout & .319 & -.17 & & .365 & -.04 \\
Parents vote for children & .288 & -.25 & & .344 & -.10 \\
Reduce voting age to 16 & .350 & -.08 & & .373 & -.02 \\
Proportional educ. subsidy* & .445 & .16 & & .419 & .10 \\
\hline \hline
\end{tabular}

Table 6: Counterfactuals (US voting policies)

Notes: The percentage change is computed relative to the US benchmark model.

*The voting simulation for the proportional education subsidy exhibits voting cycles and does not converge, but oscillates around the presented values. 


\begin{tabular}{|c|c|c|c|c|c|c|c|}
\hline & \multirow[b]{2}{*}{ Age } & \multicolumn{3}{|c|}{ Voter turnout } & \multicolumn{3}{|c|}{ Party membership } \\
\hline & & $\begin{array}{l}\text { High } \\
\text { school }\end{array}$ & $\begin{array}{l}\text { Some } \\
\text { college }\end{array}$ & College & $\begin{array}{l}\text { High } \\
\text { school }\end{array}$ & $\begin{array}{l}\text { Some } \\
\text { college }\end{array}$ & College \\
\hline \multirow[t]{4}{*}{ US } & $18-32$ & .26 & .29 & .30 & .37 & .37 & .37 \\
\hline & $33-48$ & .32 & .48 & .64 & .29 & .48 & .61 \\
\hline & $48-64$ & .47 & .63 & .77 & .44 & .58 & .75 \\
\hline & $65-80$ & .58 & .73 & .80 & .53 & .88 & .71 \\
\hline \multirow[t]{4}{*}{ Canada } & $18-32$ & .78 & .78 & .78 & .14 & .14 & .14 \\
\hline & $33-48$ & .80 & .95 & .90 & .10 & .25 & .19 \\
\hline & $49-64$ & .88 & .94 & .96 & .15 & .19 & .30 \\
\hline & $65-80$ & .95 & .99 & .97 & .17 & .13 & .16 \\
\hline \multirow[t]{4}{*}{ Denmark } & $18-32$ & .82 & .80 & .77 & & & \\
\hline & $33-48$ & .89 & .90 & .94 & & & \\
\hline & $49-64$ & 93 & .99 & .95 & & & \\
\hline & $65-80$ & .97 & .98 & .96 & & & \\
\hline \multirow[t]{4}{*}{ Finland } & $18-32$ & .63 & .82 & .84 & .08 & .08 & .08 \\
\hline & $33-48$ & .66 & .76 & .88 & .10 & .14 & .11 \\
\hline & $49-64$ & .75 & .90 & .92 & .10 & .22 & .27 \\
\hline & $65-80$ & .88 & .92 & .91 & .19 & .12 & .17 \\
\hline \multirow[t]{4}{*}{ Germany } & $18-32$ & .68 & .88 & .88 & .04 & .04 & .04 \\
\hline & $33-48$ & .68 & .83 & .92 & .06 & .04 & .10 \\
\hline & $49-64$ & .78 & .87 & .93 & .07 & .05 & .15 \\
\hline & $65-80$ & .89 & .97 & .97 & .06 & .12 & .18 \\
\hline \multirow[t]{4}{*}{ Norway } & $18-32$ & .69 & .81 & .93 & .08 & .08 & .08 \\
\hline & $33-48$ & .85 & .91 & .90 & .14 & 20 & .12 \\
\hline & $49-64$ & .86 & .92 & .93 & .22 & .28 & .26 \\
\hline & $65-80$ & .88 & .97 & .98 & .19 & .21 & .39 \\
\hline \multirow[t]{4}{*}{ Sweden } & $18-32$ & .86 & .94 & .98 & .07 & .07 & .07 \\
\hline & $33-48$ & .93 & .91 & .94 & .11 & .13 & .11 \\
\hline & $49-64$ & .95 & .99 & .97 & .17 & .13 & .16 \\
\hline & $65-80$ & .95 & 1 & 1 & .16 & .24 & .34 \\
\hline \multirow[t]{4}{*}{ UK } & $18-32$ & .48 & .72 & .49 & .08 & .08 & .08 \\
\hline & $33-48$ & .65 & .65 & .81 & .08 & .15 & .10 \\
\hline & $49-64$ & .77 & .83 & .87 & .13 & .16 & .28 \\
\hline & $65-80$ & .82 & .95 & .96 & .11 & .10 & .14 \\
\hline
\end{tabular}

Data source: CPS November voting supplement 2006, European Social Survey 2010, World Values Survey 1981-2007, Canadian Election Study 2010. Missing values are left blank. Notes: Age at time of elections. Age group 18-32 is weighted by parental education when information is available. The displayed voting weight of age group 18-32 is multiplied by 7/8 when fed into the model to reflect fact that they turn 18 after $1 / 8$ of the period.

Table 7: Voting weights based on voter turnout and party membership 


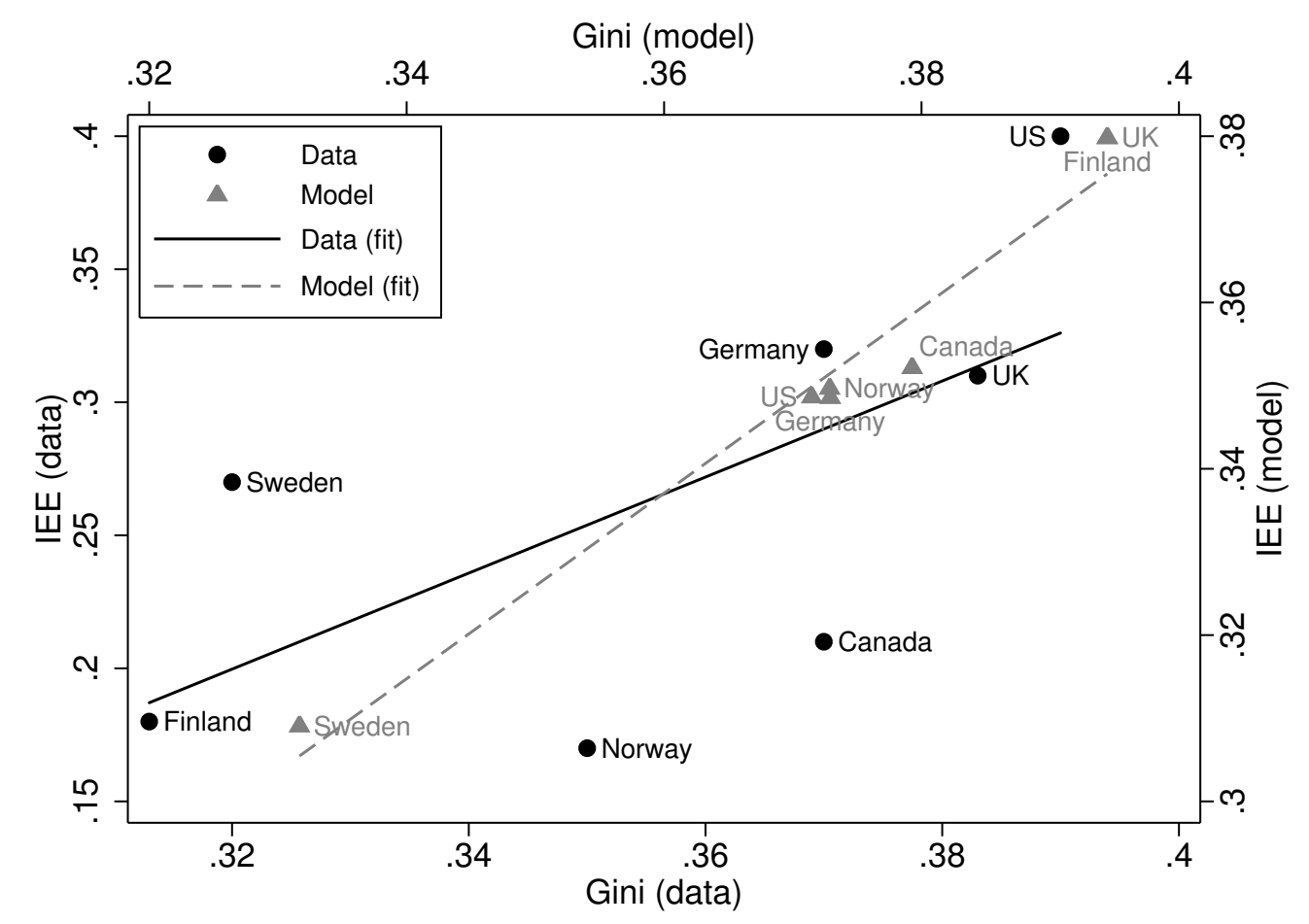

Figure 5: Inequality versus intergenerational earnings persistence (data versus party membership experiment)

Data source: See Section 7.1.

Notes: The figure compares model moments with country-specific party membership by age and education (gray) and data moments (black) of the earnings Gini before taxes and transfers (x-axis) versus IEE (y-axis). The black solid line represents a linear fit of the data moments, whereas the gray dashed line represents a linear fit of model moments. The bottom $\mathrm{x}$-axis and left $\mathrm{y}$-axis refer to the data moments, while the top $\mathrm{x}$-axis and right $\mathrm{y}$-axis refer to the model moments. 